\title{
Microalgal Biomass Generation via Electroflotation: A Cost-Effective Dewatering Technology
}

\author{
Jaison Jeevanandam ${ }^{1}$, Mohd Razif Harun ${ }^{2}$, Sie Yon Lau ${ }^{3}{ }^{\mathbb{D}}$, Divine D. Sewu ${ }^{4,5}$ \\ and Michael K. Danquah ${ }^{6, *}$ \\ 1 CQM-Centro de Química da Madeira, MMRG, Campus da Penteada, Universidade da Madeira, \\ 9020-105 Funchal, Portugal; jaison.jeevanandam@staff.uma.pt \\ 2 Department of Chemical \& Environmental Engineering, Faculty of Engineering, Universiti Putra Malaysia, \\ Serdang 43400, Malaysia; mh_razif@upm.edu.my \\ 3 Department of Chemical Engineering, Faculty of Engineering and Sciences, Curtin University, \\ Sarawak 98009, Malaysia; johnlsy@curtin.edu.my \\ 4 Life Green Technology Co. Ltd., 875 Yuseong-daero, Yuseong-gu, Daejeon 34158, Korea; \\ sewudivine@hanbat.ac.kr \\ 5 Department of Chemical and Biological Engineering, Hanbat National University, 125 Dongseo-daero, \\ Yuseong-gu, Daejeon 34158, Korea \\ 6 Chemical Engineering Department, University of Tennessee, Chattanooga, TN 37403, USA \\ * Correspondence: michael-danquah@utc.edu; Tel.: +1-423-425-4096
}

Received: 18 November 2020; Accepted: 14 December 2020; Published: 18 December 2020

\begin{abstract}
Microalgae are an excellent source of bioactive compounds for the production of a wide range of vital consumer products in the biofuel, pharmaceutical, food, cosmetics, and agricultural industries, in addition to huge upstream benefits relating to carbon dioxide biosequestration and wastewater treatment. However, energy-efficient, cost-effective, and scalable microalgal technologies for commercial-scale applications are limited, and this has significantly impacted the full-scale implementation of microalgal biosystems for bioproduct development, phycoremediation, and biorefinery applications. Microalgae culture dewatering continues to be a major challenge to large-scale biomass generation, and this is primarily due to the low cell densities of microalgal cultures and the small hydrodynamic size of microalgal cells. With such biophysical characteristics, energy-intensive solid-liquid separation processes such as centrifugation and filtration are generally used for continuous generation of biomass in large-scale settings, making dewatering a major contributor to the microalgae bioprocess economics. This article analyzes the potential of electroflotation as a cost-effective dewatering process that can be integrated into microalgae bioprocesses for continuous biomass production. Electroflotation hinges on the generation of fine bubbles at the surface of an electrode system to entrain microalgal particulates to the surface. A modification of electroflotation, which combines electrocoagulation to catalyze the coalescence of microalgae cells before gaseous entrainment, is also discussed. A technoeconomic appraisal of the prospects of electroflotation compared with other dewatering technologies is presented.
\end{abstract}

Keywords: microalgae; dewatering; electroflotation; biomass; scale-up; process economics

\section{Introduction}

Microalgae are microscopic algae that are widely found in marine and freshwater systems, and live in sediments and water column [1]. These microalgae are an excellent source of bioactive compounds for the production of a wide range of vital consumer products in the biofuel [2], pharmaceutical [3], food [4], cosmetics [5], and agricultural industries [6], in addition to huge upstream benefits relating to carbon dioxide $\left(\mathrm{CO}_{2}\right)$ biosequestration and wastewater treatment [7]. According to market research 
(United States), the global compound annual growth rate (CAGR) of microalgae between the year 2017 and 2026 is estimated at 4.6\% [8]. Furthermore, it is estimated that the revenue from the global sales of microalgae will exceed USD 75 million by the end of the year 2026 [9]. Europe was identified as the largest market for microalgae-based products in 2019, followed by North America, Asia Pacific, Latin America, Middle East, and Africa [10,11]. Microalgal products have been mostly used in food and beverage industries, followed by animal feed, nutraceutical, and dietary supplements, fuel, personal care, pharmaceutical, chemical or pigment and fertilizer industries [12]. Even though microalgae are highly beneficial for the global economy, energy-efficient, cost-effective and scalable microalgal technologies for commercial-scale applications are limited, and this has significantly impacted the full-scale implementation of microalgal biosystems for bioproduct development, phycoremediation, and biorefinery applications [13].

In general, microalgal culture is developed by the inoculation of microalgal species into a nutrient-rich culture medium, and can be maintained at ambient conditions $\left(15-30^{\circ} \mathrm{C}\right.$ in the presence of carbon dioxide) to allow growth followed by harvesting [14]. After harvesting, dewatering and drying processes are required to generate biomass for product development. The presence of water in the microalgal biomass after harvesting affects the efficiency of the extraction technique as well as the concentration and characteristics of value-added extracts. Microalgae culture dewatering continues to be a major challenge to large-scale biomass generation, and this is primarily due to the low cell densities of microalgal cultures and the small hydrodynamic size of microalgal cells [15]. With such biophysical characteristics, energy-intensive solid-liquid separation processes such as centrifugation and filtration are generally required for continuous generation of biomass in large-scale settings, making dewatering a major contributor to the microalgae bioprocess economics [16].

This article analyzes the potential of electroflotation as a cost-effective dewatering process that can be integrated into microalgae bioprocesses for continuous biomass production. Electroflotation hinges on the generation of fine bubbles at the surface of an electrode system to entrain microalgal particulates to the surface [17]. Advances in electroflotation processes have led to integration with electrocoagulation to enhance the coalescence of microalgae cells before gaseous entrainment, and this will also be discussed. A technoeconomic appraisal of the prospects of electroflotation compared with other dewatering technologies is presented.

\section{Overview of Microalgal Biosystems}

The growth characteristics and biochemical composition of microalgae are highly dependent on the cultivation conditions, which can be divided into four main categories, namely photoautotrophic, heterotrophic, mixotrophic, and photoheterotrophic [18-21]. Table 1 shows a summary of the characteristics of different microalgal cultivation conditions. Photoautotrophic cultivation is widely used to grow microalgae. The algae utilize light and $\mathrm{CO}_{2}$ (inorganic carbon) as energy and carbon sources, respectively, for growth through photosynthesis [19]. Heterotrophic cultivation offers ways to address low cell density challenges resulting from insufficient access to photons. Heterotrophic cultivation has the potential to produce higher lipid content and yield high valuable biochemical compounds from certain microalgal species. Jin et al. (2020) reported that both biomass and lipid content obtained for the unicellular alga Scenedesmus acuminatus via heterotrophic cultivation could achieve an ultra-high cell density compared to phototrophic cultivation [22]. However, the heterotrophic system is not economically feasible for commercialization as it accounts for about $80 \%$ of the total cultivation medium cost due to the requirement of additional carbon sources for growth $[23,24]$. There are limited reports on mixotrophic and photoheterotrophic cultivation of microalgae as these two methods are also limited by light requirements, contamination risks, and high operational costs.

Growth medium consists of essential nutrients (e.g., nitrogen and phosphorus), which are required to cultivate microalgae beside light and $\mathrm{CO}_{2}$. Certain microalgal species are capable of converting those freely available nutrients, such as nitrogen, phosphorus, and heavy metals from wastewater into biomass [25]. Microalgae, such as Chlorella, Scenedesmus, and Chlamydomonas can contribute to 
phyco-remediation and biomass production, simultaneously. Thus, these microalgal species, not only reduce the cost of microalgal cultivation, but also serve as a natural alternative for wastewater treatment [26]. Various microalgae cultivation systems have been developed to offer optimal biomass productivity for a specific microalgal species [27-29]. Table 2 shows different cultivation systems that have been tested and used in laboratories for large-scale production of microalgae. There are two main established technologies for microalgae cultivation namely open ponds and a controlled closed cultivation system that employs different types of photobioreactors [30]. Open ponds generally offer minimal capital and operating costs, with low energy input for culture mixing, but the risk of contamination is high.

Table 1. Characteristics of different microalgae cultivation conditions [18,19].

\begin{tabular}{cccccc}
\hline Cultivation Condition & Energy Source & Carbon Source & $\begin{array}{c}\text { Light Availability } \\
\text { Requirements }\end{array}$ & Cell Density & $\begin{array}{c}\text { Limitations and } \\
\text { Challenges }\end{array}$ \\
\hline Phototrophic & Light & Inorganic & Compulsory & $\begin{array}{c}\text { High condensation rate; } \\
\text { low cell concentration }\end{array}$ \\
\hline Heterotrophic & $\begin{array}{c}\text { Organic } \\
\text { materials }\end{array}$ & $\begin{array}{c}\text { Organic } \\
\text { materials }\end{array}$ & Not compulsory & High & $\begin{array}{c}\text { High substrate cost; } \\
\text { contamination risk }\end{array}$ \\
\hline Photoheterotrophic & Light & $\begin{array}{c}\text { Organic } \\
\text { materials }\end{array}$ & Compulsory & $\begin{array}{c}\text { High substrate cost; } \\
\text { contamination risk; high } \\
\text { equipment cost }\end{array}$ \\
\hline Mixotrophic & $\begin{array}{c}\text { Organic } \\
\text { material and } \\
\text { light }\end{array}$ & $\begin{array}{c}\text { Organic and } \\
\text { inorganic } \\
\text { materials }\end{array}$ & Not compulsory & $\begin{array}{c}\text { Medium } \\
\text { High substrate cost; } \\
\text { contamination risk; high } \\
\text { equipment cost }\end{array}$ \\
\hline
\end{tabular}

Table 2. Microalgae species and cultivation system [31].

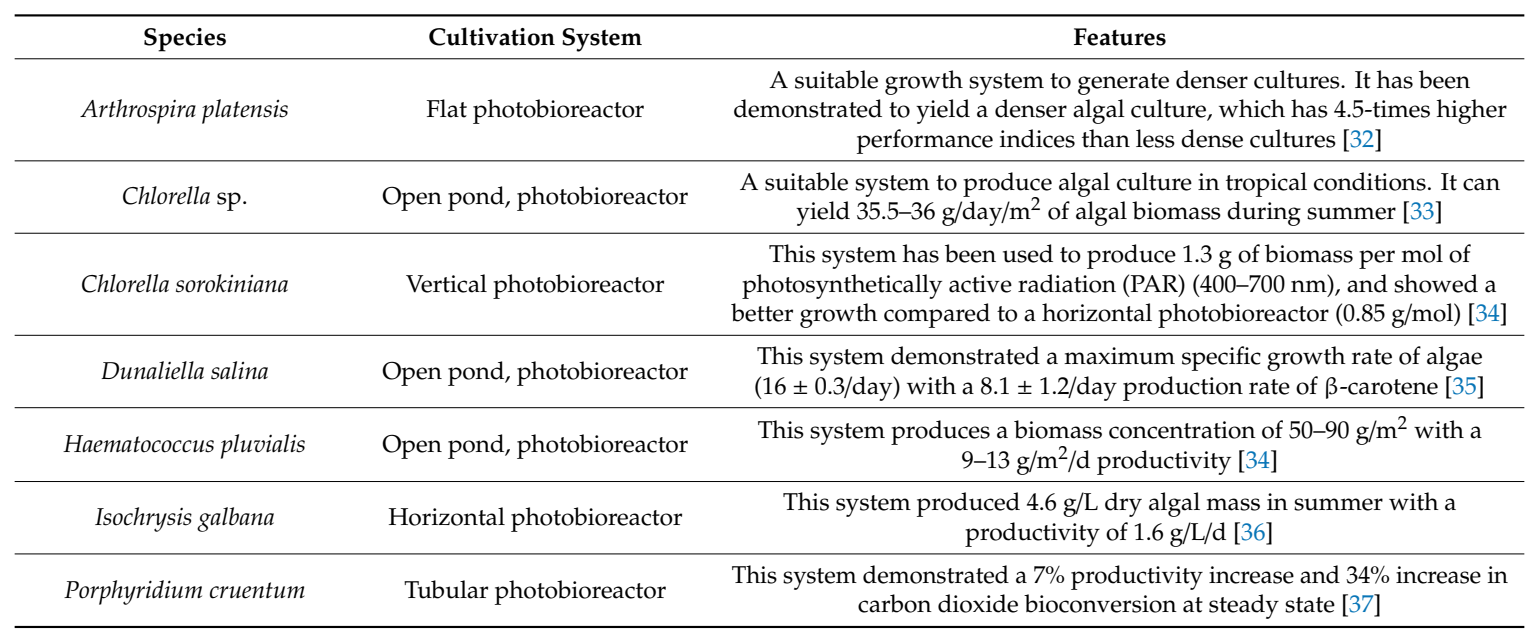

\subsection{Development of Microalgal Culture System}

There are various cultivation technologies, such as open pond, closed photobioreactor, and hybrid cultivation system in a two-stage growth, that are commonly used in recent times for the large-scale industrial culture of microalgae to extract significant compounds.

\subsubsection{Open Pond}

Open ponds or raceway ponds, including shallow big and circular pond tanks, are the simplest and one of the most intensively investigated microalgae cultivation systems, since the 1950s, due to their lower capital costs [30]. Raceway (open) pond is a shallow pond (between 0.2 and $0.5 \mathrm{~m}$ deep) to allow appropriate illumination and to attain high growth rate of microalgae [38]. Besides, biomass productivity of $60-100 \mathrm{mg} /\left(\mathrm{L} \mathrm{day}^{-1}\right)$ and biomass concentration of up to $1000 \mathrm{mg} / \mathrm{L}$ are achievable at those water depths [39]. This system is commonly applied at an industrial-scale for microalgae, and cyanobacteria cultivation, such as Anabaena sp., Arthrospira platensis, Chlorella sp., 
Phaeodactylum tricornotum, Dunaliella salina, Pleurochrysis carterae, and Nannochloropsis [40]. Further, paddle wheels are used to ensure homogenous mixing of microalgae medium around the circulate channels. For instance, by increasing the speed of the paddle wheel from 1.4 to $2.1 \mathrm{rad} \mathrm{s}^{-1}$ for an indoor open pond system using Nannochloropsis, Moazami et al. (2012) observed an increase in the biomass and lipid content of the microalgae medium [41]. The lower velocity of the paddle wheel leads to an inherent light reduction regime in raceway ponds, with microalgae cells near the bottom of the ponds being in the dark zone [42]. This layout eventually affects the biomass and lipid productivity of microalgae [43]. Hence, continuous mixing in the raceway ponds is essential to reduce the residence time of microalgae that may, otherwise, have remained in the dark regime. However, additional energy costs may be incurred since an increment in the mixing speed results in a cubical increment in the power consumption of the paddle wheel [42].

The cultivation of microalgae in raceway ponds has certain disadvantages such as high risk of culture contamination, excessive evaporation of water to the atmosphere and the extensive land requirement. Hence, only certain microalgae species can be successfully cultured in this system. Some examples include Spirulina and Dunaliella, which can withstand high alkalinity and high salinity, respectively. The selection of a proper location is vital to the successful implementation of this system; especially one with plenty of sunlight coupled with the seldom occurrence of natural disasters [31]. Outdoor scale-up microalgal cultivation for raceway ponds is normally prone to contamination. Hence, they are ideally operated under autotrophic cultivation conditions compared to other cultivation systems. Besides, raceway ponds are also restricted by certain essential growth parameters, including $\mathrm{pH}$, temperature, and dissolved oxygen concentration [31]. Even though this system is easier to construct and operate than closed photobioreactor systems, challenges that pertain to low biomass concentration due to the limited light distribution and the lack of uniformity ought to be addressed in the future in order to successfully commercialize microalgae-based biodiesel production technologies. Hence, comprehensive life cycle assessments are required to improve this cultivation system, especially on biomass productivity and system design.

\subsubsection{Closed Photobioreactor}

Photobioreactors have been extensively investigated to better control cultivation conditions, such as $\mathrm{pH}$, temperature, $\mathrm{CO}_{2}$, light intensity, and nutrient concentration to achieve optimal biological and physiological characteristics of microalgae cultures [26]. Table 3 shows a comparison between an open pond and photobioreactor, and each presents a unique set of benefits and disadvantages. A photobioreactor is a closed system that allows monoculture of microalgae for prolonged durations with high biomass productivity, short harvesting time, and low risk of contamination $[38,44]$. This system is normally used to cultivate microalgae for the production of protein, fatty acids, pigments, animal feed, and antioxidants in large-scale. Example of microalgal species that have been tested to grow in photobioreactors are Chlorella vulgaris, Chlorella sarokiniana, Arthrospira platensis, Nannochloropsis sp., Phorphyridium cruentum, Selenastrum capricornutum, Haematococcus pluvialis, and Phaeodactylum tricornotum, among others [40,45]. Specifically, photobioreactors allow higher volumetric productivity for the enhanced capture of radiant energy, depending on microalgal strains and scales used. Hence, it is expected that photobioreactor can attain higher oil yield per hectare $\left(136.9 \mathrm{~m}^{-3} \mathrm{ha}^{-1}\right.$ based on $70 \mathrm{wt} . \%$ oil in biomass) when compared to raceway pond $\left(99.4 \mathrm{~m}^{-3} \mathrm{ha}^{-1}\right)$ [46].

Photobioreactors can be placed either indoors with artificial light or outdoor using direct sunlight and they can be operated in batch or continuous mode [44]. Further, photobioreactors can be designed with distinct structures, such as tubular and flat plate. Tubular photobioreactors are preferred for outdoor cultivation of microalgae as this system can be constructed in various configurations, either in a vertical, horizontal, or inclined plane, depending on the specifications of the system. Vertical design allows better gas-liquid mass transfer and less energy consumption, while the horizontal design is scalable, but requires a large land area [47]. On the other hand, a flat-plate photobioreactor is cuboidal and equipped with a minimal light pathway. These photobioreactors can be made via transparent 
materials, such as polycarbonate, glass, and plexiglass [44], and have a high surface to volume ratio [47]. Although less study on flat-plate photobioreactors is available in the literature, it has been reported that bulk cultivation of microalgae is plausible in this system due to low accumulation of dissolved oxygen $\left(\mathrm{O}_{2}\right)$ and high illumination area [47]. However, flat-plate photobioreactor usage has resulted in a lower yield of biomass per area as compared to tubular photobioreactors due to shorter light penetration depths and lack of light dilution, which led to photo-inhibition of microalgal growth [47]. Table 4 shows the comparison between tubular and flat-plate photobioreactor systems.

Table 3. Comparison of open, closed, and hybrid microalgae photobioreactor facilitated cultivation systems [29,39].

\begin{tabular}{cccc}
\hline Parameter & Open Pond (Raceway Pond) & Closed Photobioreactors & Hybrid System \\
\hline Space required & High & Moderate & High \\
Setup cost & Low & High & Moderate \\
Contamination risk & High & Low & Low \\
Evaporation loss & High & Almost none & Noderate \\
$\mathrm{CO}_{2}$-losses & High & Almost none & Susceptible \\
Biomass quality & Not susceptible & Susceptible & High \\
Culture quality & Low & High & High \\
Growth rate & Low & High & Moderate \\
Scaling-up feasibility & Easy & Difficult & - \\
Reproducibility of production & - & Possible within certain tolerances & Continuous \\
parameters & Batch & High & Moderate \\
Operation type & Low & Difficult & Moderate \\
Energy input for mixing & Easy & Possible & - \\
Maintenance & Not possible & Insignificant as closed & - \\
Standardization & configurations allow cultivation & even during bad weather \\
Weather dependence & Absolute, cultivation is impossible & High, short time, relatively small & volume flows \\
\hline
\end{tabular}

Table 4. Comparison of tubular and flat-plate photobioreactors [47].

\begin{tabular}{|c|c|c|}
\hline Production System & Advantages & Disadvantages \\
\hline Tubular photobioreactor & $\begin{array}{l}\text { - } \\
\text { - } \\
\text { Appligh biomass productivity } \\
\text { mass cultivation } \\
\text { - } \\
\text { - } \\
\text { - } \\
\text { Cow mutual shading effect } \\
\text { Lower photo-inhibition }\end{array}$ & $\begin{array}{l}\text { - } \quad \text { High initial investment costs } \\
\text { - } \quad \text { Toxic accumulation of } \mathrm{O}_{2} \text { fouling } \\
\text { - } \\
\text { - } \\
\text { Overheating } \\
\text { Dissolved oxygen builds up }\end{array}$ \\
\hline Flat-plate photobioreactor & 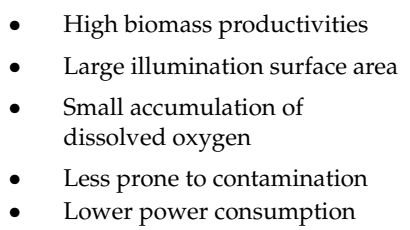 & $\begin{array}{l}\text { - } \\
\text { - } \\
\text { - } \\
\text { - Short light penetration in temperature control } \\
\text { materials and large areas of land }\end{array}$ \\
\hline
\end{tabular}

\subsubsection{Hybrid Cultivation System in Two-Stage Growth}

The two-phase hybrid cultivation system has been proposed to overcome weaknesses in both open and closed-culture systems. This system is designed to reduce the overall production and operation cost as well as to elevate biomass productivity of microalgae [38]. Besides, the hybrid system can increase lipid accumulation in microalgae [29] as it comprises two-stage cultures. The first phase of cultivation occurs in a photobioreactor, where the growth parameters are controlled to favor continuous cell division as well as to minimize contamination from other microorganisms [48,49]. In the second phase, the growing microalgae cells from the photobioreactor are transferred to open ponds and subjected to nutrient depletion and certain additional environmental stresses. The rationale is to enhance the lipid accumulation within the microalgal cells and to achieve a fatty acid composition target for biodiesel 
production $[18,49]$. High inoculum is needed in the second phase to ensure that the microalgae population rather dominates the cultivation medium and not other microbes. The comparative analysis of the hybrid cultivation system is shown in Table 3.

Huntley and Redalje (2007) used this hybrid system for the production of both astaxanthin (used in salmon feed) and oil from Haematococcus pluvialis [49,50]. Consequently, this system produced an annual average of 10-24 tonnes $\mathrm{ha}^{-1}$ per annum of lipid from Haematococcus pluvialis depending on the local climatic conditions. The study also stated that under similar conditions, it is possible to reach up to 76 tonnes ha ${ }^{-1}$ per annum, when microalgal species with higher lipid content and photosynthetic efficiency, such as Chlorella vulgaris, are used. Besides, Rodolfi et al. (2009) conducted a conceptual study on this two-stage cultivation process, where $90 \mathrm{~kg} \mathrm{ha}^{-1}$ per day of lipid production (10 and $8 \mathrm{~kg} \mathrm{ha}^{-1}$ per day in the first and second phase, respectively) could be achieved. This was done by dedicating $22 \%$ of the production plant to biomass production under nitrogen sufficient conditions, and the remaining plant to lipid production under nitrogen deficient conditions [49,51]. This system produced a lipid rate of 20 tonnes ha ${ }^{-1}$ in the Mediterranean climate and up to 30 tonnes ha ${ }^{-1}$ of lipid in sunny tropical areas. Thus, it is worth noting that the microalgae cultivation system does play a pivotal role in ensuring the high productivity of biomass production.

\section{Dewatering in Microalgal Culture}

Harvesting and dewatering is the process to eliminate water from the initial microalgal culture to acceptable solid content. This step is highly challenging as it involves handling of large water quantities, due to the dilute nature of microalgae culture; typically having low biomass concentration (less than $1 \mathrm{~g} / \mathrm{L}$ ), depending on the cultivation method [52]. Microalgae have a similar density of water, have a negatively charged surface, and are stable, which further adds to the challenge [53]. Hence, ideal dewatering and harvesting methods must be able to attain high biomass concentration and be suitable for most microalgae strains. There are several types of microalgae dewatering and harvesting techniques, that have been developed from various studies. Figure 1 illustrates the conventional dewatering and harvesting methods for microalgae culture available in the literature.

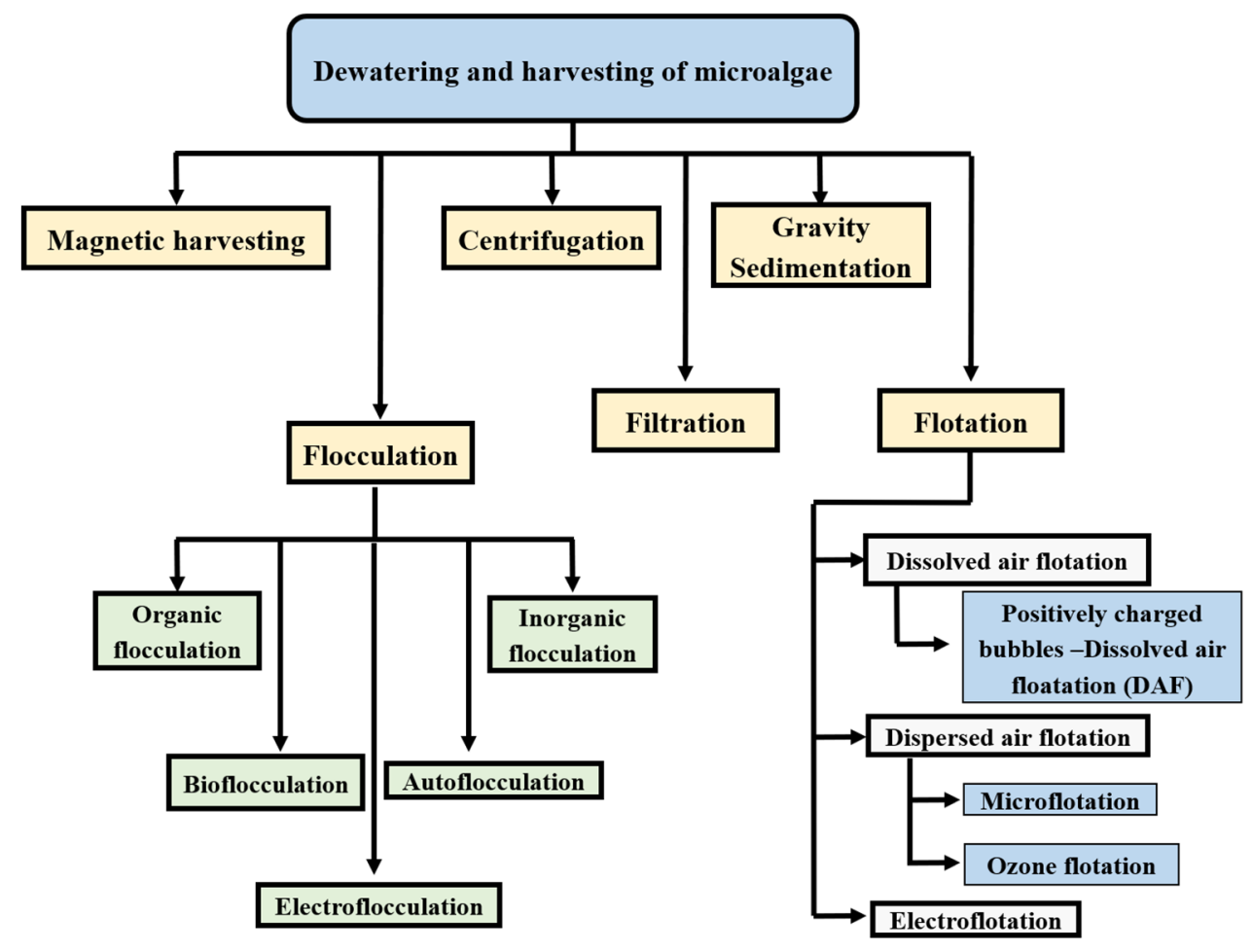

Figure 1. Conventional microalgae harvesting and dewatering methods. 


\section{Conventional Dewatering Approaches in Microalgal Culture}

Flocculation, flotation, gravity sedimentation, centrifugation, and filtration are the conventional dewatering approaches used in microalgal culture. Even though these methods are beneficial in eliminating water, certain limitations such as an increase in cost and decrease in the yield exist. Thus, several advanced methods are introduced as hybrid techniques along with these conventional approaches to enhance the dewatering efficiency.

\subsection{Flocculation}

Flocculation is a promising low-cost method that is considered as the initial economic step in dewatering and harvesting processes. Flocculation is also sometimes interchangeably referred to as coagulation. However, they are defined differently. Coagulation involves the adjustment of $\mathrm{pH}$ and addition of electrolyte, whereas flocculation is based on the cationic addition of polymers to the samples. However, both coagulation and flocculation are reported to perform in the same way [52]. Flocculation occurs by the interaction of the negatively charged surface of microalgae cells with the flocculants, and cells will further aggregate into larger particles. Microalgae cells exhibit negatively charged surface and are stabilized due to the presence of carboxylic (-COOH), phosphate (-PO4), and amine (-NH2) groups on their cell surface. The carboxyl group will dissociate at $\mathrm{pH}$ above $4-5$, whereas amine will be uncharged at this $\mathrm{pH}$, causing microalgae cells to pose net opposing surface charge above $\mathrm{pH} 4-5$ [54]. Further, flocculation suits various microalgal strains of sizes between 5 and 5 microns [55], compared to other harvesting methods. Furthermore, several factors affect microalgae flocculation, such as $\mathrm{pH}$ (5 or 10), type, and dosage of the flocculants (e.g., aluminum sulfate at low dosage of $<37 \mathrm{mg} / \mathrm{L}$ and high dosage of $70 \mathrm{mg} / \mathrm{L}$ ), mixing intensity, size, and surface characteristics of algal cells (zeta potential), ionic strength (high ionic strength changes surface charge to positive), initial biomass concentration, the composition of the culture medium, and the motility of microalgae to some extent [56]. Additionally, microalgae contain algal organic matter (AOM), which also influences flocculating activity as well as in the harvesting of microalgae. These AOMs (10.6 and $58.5 \mu \mathrm{g} / \mathrm{mL}$ to 2.3 and $5.6 \mu \mathrm{g} / \mathrm{mL}$ for Chlorella vulgaris and Nannochloropsis oculata, respectively) are secreted mainly from the extracellular polysaccharide substances (EPS) by microalgae cells that produce proteins or polysaccharides. Later, these compounds are identified to react with flocculants, which can result in high flocculants demand and affect the dewatering process [57]. The impact on the environment, the reusability of the resultant supernatant or recycling of medium, price, and absence of harvested biomass contamination, post-usage of flocculants must be considered in selecting a suitable flocculant [52].

Organic flocculants are safer alternatives and environmentally friendlier choices of polymers or polyelectrolytes, compared to inorganic flocculants. In general, these polymers are categorized as cationic, anionic, and nonionic polymeric flocculants. Anionic flocculants may cause electro-repulsion with negatively charged microalgae cells. Thus, cationic polymers are more successful in flocculating microalgae cells [58]. Further, polymer flocculants can form a bridge that can physically bind with one or more particles together, rather than just neutralizing the surface charge [59]. Chitosan, an example of cationic polymers derived from chitin, is widely used to harvest microalgae (self-flocculating agent with about $22 \pm 2 \%$ efficiency in the stationary phase), due to its environmentally friendly nature, the reusability of the residual medium, and the further utilization of the dewatered biomass in field applications [60,61]. Additionally, other plant-based flocculants such as Moringa oleifera seed extract ( $93 \%$ of C. vulgaris) and mung bean protein extract (90\% of Nannochloropsis sp.) possess microalgae dewatering potential [62,63]. Furthermore, inorganic flocculants such as aluminum sulphate, ferric chloride, and ferric sulphate are commonly used. These, however, vary in effectiveness due to their ionic charge [52]. Aluminum sulphate is widely used to treat industrial wastewater and is highly effective compared to other metal salts in flocculating freshwater or marine species of microalgae. However, the use of these inorganic flocculants is reported to be affected by several factors, such as $\mathrm{pH}$, solubility, electronegativity, and ionic charge density [52]. 


\subsection{Gravity Sedimentation}

Sedimentation is a simple process for solid and liquid separation, compared to other dewatering methods. It works by gravitational forces with low power consumption and low cost [64]. Separation by sedimentation depends on particle density and size, where a greater difference in density provides rapid sedimentation and vice versa for a lower difference in density [2]. The suitability of this method only accounts for the larger particle size of microalgae that are more than $70 \mu \mathrm{m}$ including Spirulina. However, it is still relatively slow, due to the low specific gravity of algal cells [15,59]. Generally, coagulation or flocculation is needed before sedimentation to improve the settling of microalgae. This method is not widely used in the industry, though it can concentrate microalgal suspensions up to $1.5 \%$ of total suspended solids [64]. Even though the cost associated with this method is low, it requires longer settling time ( $24 \mathrm{~h}$ to 15 days) than other processes and relies on flocculating agents (alum, ferric sulphate) to facilitate the process. Moreover, the cell concentration obtained from gravity sedimentation is still low as well as the energy demand for pumping the slurry (60-65\% of cell recovery efficiency) [64].

\subsection{Centrifugation}

Centrifugation is another method to dewater microalgal culture that works by centrifugal forces depending on the cell size and culture density. Several centrifugal approaches such as a decanter, disc stack centrifuge, multichamber centrifuge, hydroclone, and the nozzle type centrifuge can be applied for microalgae separation. Among these types of centrifuges, some of them are carried out as a step separation process, while others need preconcentrated steps [65]. Disc stack centrifuge is suitable for separating material with 3-30 $\mu \mathrm{m}$ of particle sizes and can concentrate the suspensions from $2 \%$ to $25 \%$ solid content [2]. On the other hand, decanter centrifuge is less suitable for microalgae suspension as it is only applicable to separate materials that are higher than $15 \mu \mathrm{m}$ in size and concentrate suspensions higher than $15 \%$ of solid content [2].

\subsection{Filtration}

Filtration approach is used to separate microalgae, and water, either via physical, biological, or chemical methods, that allow the suspension to pass through specific filters, such as membranes, screens, or microstrainers. The pressure difference across the filters is important to move the fluids, driven by either pressure, gravity, centrifugal, vacuum, or magnetic filtration [55,64]. There are numerous types of filtration systems, such as vacuum, centrifugal, gravity, floating, and multilayer systems. In recent times, membrane filtration has received ample attention due to its proven effectiveness in microalgae recoveries. The membrane pore sizes are generally classified as ultrafiltration for $0.02-2 \mu \mathrm{m}$, microfiltration for $0.1-10 \mu \mathrm{m}$ and macrofiltration for more than $10 \mu \mathrm{m}$ pore sizes [2].

Membrane filtration is suitable for dewatering and harvesting of fragile cells. It has the ability to dewater microalgae at a very low cell density [65], whereas microfiltration and ultrafiltration are effective at dewatering smaller algae [59]. The dewatering of microalgae can be achieved by applying these membranes to the tangential flow filtration system (TFF). The TFF, also known as cross-flow filtration, has a promising potential for microalgae harvesting, where the medium flows tangentially across the membrane with about $70-89 \%$ of microalgae biomass recovery [66]. Further, TFF was reported to concentrate Tetraselmis suecica microalgae up to 148 times with only $2.06 \mathrm{kWh} / \mathrm{m}^{3}$ energy consumption compared to flocculation which consumes up to 357 times more energy at $14.81 \mathrm{kWh} / \mathrm{m}^{3}$ [66]. However, the benefit of a longer life span of the membrane in dewatering may be achieved if used under low imposed transmembrane pressure and low cross-flow velocity. Furthermore, fouling and membrane replacement also contributes to the high-cost consumption for large-scale recovery of microalgae, which is considered as the major limitation of filtration techniques [55]. 


\subsection{Flotation}

Flotation is a gravity separation process to capture particles below $500 \mu \mathrm{m}$ using air or gas bubbles. This technique is commonly applied in wastewater treatment, and usually requires prior coagulation or flocculation to enhance the removal efficiency. The success of the flotation method relies on the bubble-particle collision and adhesion process. Thus, it depends on the instability of the suspended particle, as the lower instability will increase the air-particle contact $[52,55,58]$. The size of the particles is highly significant for this technique, where the smaller size of the particles will lead to ease in lifting the bubbles to the surface. Therefore, the particle size of the suspension is suitable for flotation [64]. Various types of flotation methods are based on the formation of bubbles, including dissolved air flotation (DAF), dispersed air flotation, and electrolytic flotation.

\section{Electroflotation-Facilitated Dewatering for Microalgal Biomass Generation}

Electroflotation is a variant of the flotation technique that utilizes an electrode system with the passage of electricity to generate microbubbles (17-50 $\mu \mathrm{m}$ in diameter [67]) to entrain suspended microalgal particles via collision and adhesion [68], which consequently causes floating due to buoyancy effects as shown in Figure 2. Electroflotation is one of three main electrolytic (electrochemical) dewatering techniques, where the others are electrocoagulation and electroflocculation, that are highlighted as harboring the potential for large-scale dewatering of microalgal cultures at lower energy, lower costs, higher efficiency, and easier operation, compared to several conventional approaches [69]. However, the literature is replete with the loose usage of the aforementioned terms associated with electrolytic dewatering techniques, which has led to warranted confusion. A description, given by Uduman et al. (2010) [55], which was cited over 1105 times (google scholar as of 1 November 2020) and referenced by National Alliance for Advanced Biofuels and Bioproducts (NAABB), distinguishes electroflotation from the other electrolytic techniques based on the electrode system, which determines the dominant products or half-reactions at each electrode, and the primary function of the setup as shown in Table $5[69,70]$. Thus, they define electroflotation as an electrically driven method that uses a reactive metal anode and an inactive or inert metal cathode, respectively, generates metal ions in situ, and creates hydrogen bubbles from the electrolysis of water [69]. The principal reactions that occur at the electrodes along with a general description of the electroflotation process are shown in Figure 2. Oxygen evolution for this setup occurs at higher current densities [71]. Notwithstanding that, electroflotation is intrinsically tied to electrocoagulation and electroflocculation due to the accompanying water electrolysis, which generates microbubbles, probably to a lesser extent, that ultimately float some microalgae particles [72].

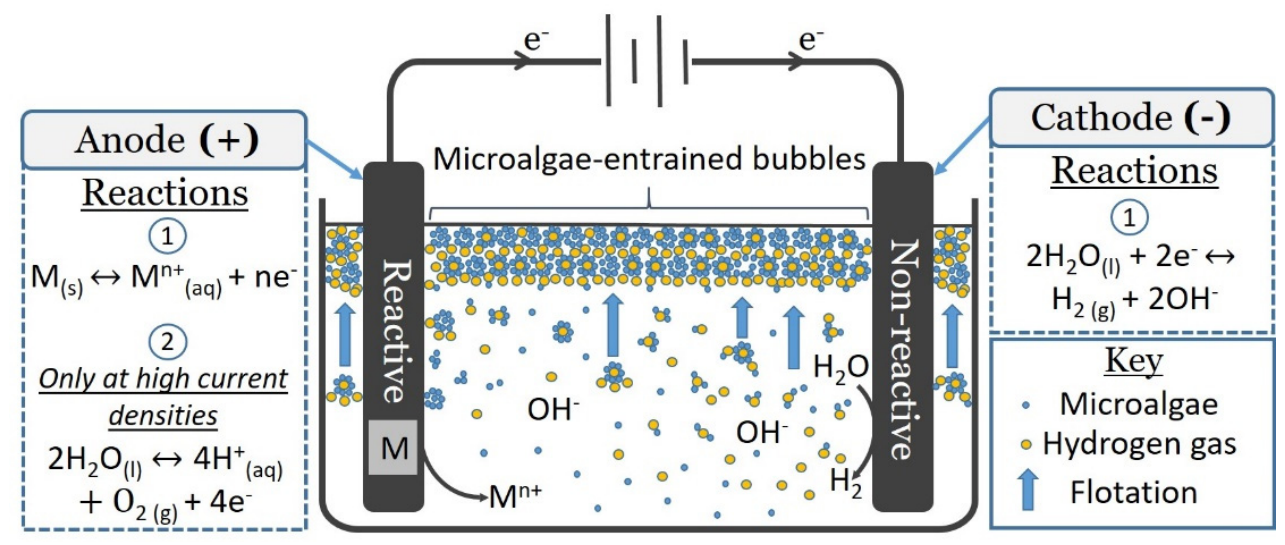

Figure 2. Diagrammatic description of an electroflotation-based microalgal dewatering process. 
Table 5. Simplified description of the main electrolytic dewatering techniques in microalgal biomass generation.

\begin{tabular}{|c|c|c|c|}
\hline \multirow[t]{2}{*}{ Electrolytic Technique } & \multicolumn{2}{|c|}{$\begin{array}{c}\text { Reactive State of Electrodes } \\
\text { (Dominant Products or Occurrences) }\end{array}$} & \multirow[t]{2}{*}{ Primary Function } \\
\hline & Anode (+) & Cathode (-) & \\
\hline Electrocoagulation & $\begin{array}{c}\text { Reactive } \\
\text { (metal dissolution) }\end{array}$ & $\begin{array}{c}\text { Reactive } \\
\text { (reductive metal } \\
\text { deposition) }\end{array}$ & Induce coagulation \\
\hline Electroflotation & $\begin{array}{c}\text { Reactive } \\
\text { (metal dissolution) }\end{array}$ & $\begin{array}{c}\text { Nonreactive } \\
\left(\mathrm{H}_{2} \text { formation }\right)\end{array}$ & Generate microbubbles \\
\hline Electroflocculation & $\begin{array}{c}\text { Nonreactive } \\
\left(\mathrm{O}_{2} \text { formation }\right)\end{array}$ & $\begin{array}{l}\text { Nonreactive } \\
\left(\mathrm{H}_{2} \text { formation }\right)\end{array}$ & Production of microalgal flocs \\
\hline
\end{tabular}

\subsection{Performance Estimation of Electroflotation-Based Dewatering Process}

The electroflotation dewatering performance is a function of several variables such as current density, voltage, electrolysis time, conductivity, initial solution $\mathrm{pH}$, electrode materials, and flow velocity. That notwithstanding, the performance of electroflotation in generating microalgal biomass via dewatering can be estimated based on energy consumption, microalgae recovery efficiency, and/or the operational costs. The energy consumption is often in units of $\mathrm{kWh} / \mathrm{kg}$ of recovered microalgae and computed from Equation (1).

$$
\text { Energy consumption, } E\left(\frac{\mathrm{kWh}}{\mathrm{kg}}\right)=\frac{U \times I \times t}{1000 V \times \eta \times C_{i}}
$$

where $U$ is the applied voltage $(\mathrm{V}), I$ is the current $(\mathrm{A}), t$ is the electrolysis time (h), $V$ is the volume of the microalgal solution treated $\left(\mathrm{m}^{3}\right), \eta$ is the recovery efficiency of the microalgae (\%), and $C_{i}$ is the initial concentration of the microalgae biomass $\left(\mathrm{kg} / \mathrm{m}^{3}\right)$ [73].

The microalgae recovery efficiency, $\eta$, is determined via indirect measurements of pre- and post-electroflotation concentrations of microalgae from turbidity or optical density data at specific wavelengths using Equation (2).

$$
\text { Microalgae recovery ef ficiency, } \eta(\%)=\left(\frac{O D_{f}-O D_{i}}{O D_{i}}\right) \times 100
$$

where $O D_{i}$ and $O D_{f}$ are the initial and final optical densities, respectively.

\subsection{Factors Affecting the Performance of Electroflotation-Based Microalgal Dewatering Process}

Typically, in flotation systems, and by extension, electroflotation systems, smaller bubble sizes are preferred owing to the higher surface area-to-volume ratio [74]. As such, the success of electroflotation in generating microalgal biomass via efficient dewatering is largely dependent on the quality of microbubbles, such as size, quantity, and distribution, which is closely intertwined with factors such as the process conditions, characteristics of the electrodes, and condition of the microalgal broth and/or electrolyte $[17,75]$.

\subsubsection{Process Conditions}

The process conditions or parameters may include current, voltage, electrolysis time, interelectrode distance, and mixing rate; for inculcation into a continuous system, flow velocity and liquid depth may be equally important. Electricity in the form of current is the driving force for electroflotation, and dictates the cathode and anode reaction rates, which in turn governs bubble evolution from the generated $\mathrm{H}_{2}$ and $\mathrm{O}_{2}$ gases, respectively $[17,76]$. It is worth noting that, according to Equation (1), the current, voltage, and electrolysis time amongst other parameters govern energy consumption and dewatering efficiency in electroflotation. For instance, Shin et al. (2017) studied the effect of the current increment on microalgae (Scenedesmus obliquus UTEX 393) dewatering efficiency and 
observed that in $10 \mathrm{~min}$, the latter increased and reached $80 \%$ at $0.25 \mathrm{~A}$, and over $90 \%$ in both 0.5 and 0.75 A supplied current. The authors explained that the increased efficiency was due to higher ion mass transport between the electrodes with the current increase [17]. Nevertheless, caution must be exercised in applying high currents as this translates to more power consumption (Equation (1)) and may lead to higher costs and energy wastage. This was illustrated in the aforementioned experiment, where approximately half the energy consumption at $0.75 \mathrm{~A}(1.516 \mathrm{Wh} / \mathrm{g})$ was needed at $0.5 \mathrm{~A}(0.834 \mathrm{Wh} / \mathrm{g})$ to achieve similar harvesting efficiency (>95\%); $0.75 \mathrm{~A}$ will thus, have no added benefit to the efficiency of the process. The electrolysis time is another key variable in controlling the performance of electroflotation. For a given current supply, longer electrolysis time can lead to a dewatering efficiency of almost $100 \%$ [77], after which any additional time will ramp up the cost of the electroflotation process.

For electroflotation, the required electrolysis voltage is mainly from the ohmic potential drop of the aqueous phase and it is directly proportional to the interelectrode distance. The interelectrode distance is especially important when the electrolyte conductivity is low, as higher current densities must be applied to overcome the ohmic potential drop of the aqueous phase. This inadvertently leads to a large consumption of energy [67] which is undesirable. The frequently used interelectrode distances in literature for electroflotation to generate microalgal biomass, range from 1.0 to $4.4 \mathrm{~cm}$ as shown in Table 6 for vertically oriented electrodes. 
Table 6. Set of conditions utilized in dewatering of microalgae via electroflotation for microalgal generation.

\begin{tabular}{|c|c|c|c|c|c|c|c|c|c|c|c|c|c|c|c|}
\hline \multirow[b]{2}{*}{ Microalgae } & \multirow{2}{*}{$\begin{array}{l}\text { Production } \\
\text { Scale }\end{array}$} & \multicolumn{5}{|c|}{ Electrode Characteristics } & \multicolumn{3}{|c|}{ Microalgal Broth Conditions } & \multicolumn{3}{|c|}{ Process Conditions } & \multicolumn{2}{|c|}{$\begin{array}{l}\text { Performance } \\
\text { Indicators }\end{array}$} & \multirow[t]{2}{*}{ Referenc } \\
\hline & & $\begin{array}{l}\text { Anode } \\
\text { (Active) }\end{array}$ & $\begin{array}{l}\text { Cathode } \\
\text { (Inactive) }\end{array}$ & $\begin{array}{l}\text { IED } \\
(\mathrm{cm})\end{array}$ & No. & $\begin{array}{c}\text { Config. } \\
\text { (Geometry) }\end{array}$ & $\begin{array}{l}\text { Salinity/ } \\
\text { Cond. } \\
\text { (mS/cm) }\end{array}$ & $\begin{array}{c}\text { Initial Cell } \\
\text { Density }(\mathrm{g} / \mathrm{L})\end{array}$ & $\mathrm{pH}$ & $\begin{array}{c}\mathrm{MR} \\
(\mathrm{rpm})\end{array}$ & I (A) & $\begin{array}{l}\text { Time } \\
(\min )\end{array}$ & $\begin{array}{c}\mathrm{E} \\
(\mathrm{kWh} / \mathrm{kg})\end{array}$ & $\eta(\%)$ & \\
\hline $\begin{array}{l}\text { Chlorella vulgaris } \\
\text { (freshwater) }\end{array}$ & $\begin{array}{l}\text { Lab.-scale } \\
\text { (batch) }\end{array}$ & $\mathrm{Al}$ or $\mathrm{Fe}$ & $\mathrm{IrO}_{2} / \mathrm{TiO}_{2}$ & 4.4 & 2 & $\begin{array}{c}\text { Vertical } \\
\text { placement (flat } \\
\text { plates) }\end{array}$ & 0.8 & $0.3-0.6$ & $\begin{array}{r}4, \\
6,8\end{array}$ & $\begin{array}{c}0, \\
60 \\
150, \\
200\end{array}$ & $1.5^{\mathrm{a}}$ & 30 & 2.1 & 88 & [73] \\
\hline $\begin{array}{l}\text { Phaeodactylum } \\
\text { tricornutum } \\
\text { (marine) }\end{array}$ & $\begin{array}{l}\text { Lab.-scale } \\
\text { (batch) }\end{array}$ & $\mathrm{Al}$ or $\mathrm{Fe}$ & $\mathrm{IrO}_{2} / \mathrm{TiO}_{2}$ & 4.4 & 2 & $\begin{array}{c}\text { Vertical } \\
\text { placement (flat } \\
\text { plates) }\end{array}$ & 43 & $0.3-0.6$ & $\begin{array}{r}4 \\
6,8\end{array}$ & $\begin{array}{c}0 \\
60 \\
150 \\
200 \\
\end{array}$ & $0.6^{\mathrm{a}}$ & 20 & 0.2 & 85 & [73] \\
\hline $\begin{array}{l}\text { Microcystis sp. } \\
\text { (freshwater) }\end{array}$ & $\begin{array}{l}\text { Batch and } \\
\text { conti. }\end{array}$ & $\mathrm{Al}$ & Ti alloy & 1.5 & 2 & $\begin{array}{c}\text { Vertically placed } \\
\text { (plates) }\end{array}$ & 0.3 & $\begin{array}{c}\text { Batch: } \\
0.0003-0.0015\end{array}$ & $7.6-7.8$ & $\begin{array}{r}0,100 \\
275,550\end{array}$ & $(0.8-4.3)^{\mathrm{b}}$ & $\begin{array}{l}\text { Cont. } \\
(2-35)\end{array}$ & n.r. & $\approx 100$ & {$[78]$} \\
\hline $\begin{array}{c}\text { Scenedesmus } \\
\text { obliquus UTEX } 393\end{array}$ & $\begin{array}{c}\text { Lab.-scale } \\
\text { (batch) }\end{array}$ & $\mathrm{Al}$ & $\mathrm{Ti} / \mathrm{IrO}_{2}$ & n.r. & 2 & $\begin{array}{l}\text { Perforated } \\
\text { plate-type }\end{array}$ & $\begin{array}{c}10-30 \% \text { seawater } \\
\text { addition }\end{array}$ & 1.05 & n.r. & 350 & $\begin{array}{c}0.25, \mathbf{0 . 5} \\
0.75 \\
\end{array}$ & 10 & 0.68 & $>95$ & {$[17]$} \\
\hline $\begin{array}{l}\text { Nannochloris } \\
\text { oculata } \\
\text { (KMMCC-16) }\end{array}$ & Conti. & $\mathrm{Al}$ & $\mathrm{Ti}-\mathrm{RbO}_{2}$ & 1.0 & 2 & Plates & n.r. & 1.0 & $4,6,8$ & 150 & $\begin{array}{c}\mathbf{0 . 2 5}, 0.5 \\
0.75\end{array}$ & 15 & 0.63 & 79.8 & [79] \\
\hline
\end{tabular}

Note: Prod. scale: production scale; Lab.-scale: laboratory-scale; conti.: continuous system; n.r.: not reported; Ref.: reference; IED: interelectrode distance; No.: number of electrodes; MR: mixing rate; I: electrical current; cond.: conductivity; config.: configuration; E: energy consumption; $\eta$ : microalgae recovery efficiency; ${ }^{\mathrm{a}}$ : current density $\left(\mathrm{mA} / \mathrm{cm}^{2}\right)$; ${ }^{\mathrm{b}}$ : volumetric current intensity $\left(\mathrm{A} / \mathrm{dm}^{3}\right)$; bold texts signify optimum or selected condition. 
Most research found that mixing rate or agitation was not a decisive factor in enhancing removal performance of the microalgal cultures with electroflotation [80]. Notwithstanding that, Alfafara et al. (2002) showed that the above deduction held in higher electrical input power, where there is a corresponding increase in the electrophoretic movements of the particles. Heightened mixing in this case can even hamper the microalgae recovery efficiency via floc destruction or dispersion of entrapped gas microbubbles inside the algal clumps [78]. However, external mixing for low electrical input power may be proven to be helpful in increasing the bubble-microalgae collision frequency and consequently enhancing microalgae recovery. Similar observations were also reported by Kim et al. (2012) [79].

For a continuous process, other parameters such as liquid depth and flow velocity are essential as they govern the collision probability between hydrogen microbubbles and microalgae [68]. An investigation into this was executed by Luo et al. (2017), who found that, when all other parameters were fixed except for the increase in liquid depth, microalgae cells in the foam correspondingly increased [68]. However, higher pressures at deeper depths impeded the quick release of hydrogen gas bubbles from the electrode surface, which raised the energy consumption. Even in cases where the hydrogen bubbles were released, they reached saturation easily, in terms of the maximum number of microalgae cells floatable per bubble and could no longer entrain more microalgae beyond certain depths. To achieve high microalgae dewatering efficiency, optimization of the process parameters is thus essential.

\subsubsection{Electrode Characteristics}

For an efficient electroflotation system, attention must be accorded to the electrode-related characteristics such as the material of construction, polished state of the surface, electrode number, and configuration, geometry, and size [77]. The electrodes are the major site of reactions and can be classified as either anode, where oxidation reactions occur, or cathode, where reduction reactions occur as shown in Figure 2. It is, thus, important that the selected electrode is effective and cheap [81]. Diverse materials such as aluminum (Al), iron (Fe), zinc $(\mathrm{Zn})$, copper $(\mathrm{Cu})$ as anodes and stainless steel, carbon/graphite $(\mathrm{C})$, titanium (Ti) alloys like iridium oxide/titanium dioxide $\left(\mathrm{IrO} / / \mathrm{TiO}_{2}\right)$, titanium/iridium oxide $\left(\mathrm{Ti} / \mathrm{IrO}_{2}\right)$, and titanium/rubidium oxide $\left(\mathrm{Ti} / \mathrm{RbO}_{2}\right)$ as cathodes have been used and each affected bubble characteristics and the performance of the electroflotation process differently as mentioned in Table 6. Many studies have found that under similar experimental conditions, using $\mathrm{Al}$ as an anode outperforms $\mathrm{Fe}$ in terms of quantity of dewatered and harvested microalgae. For instance, Vandamme et al. (2011) investigated the use of either $\mathrm{Al}$ or $\mathrm{Fe}$ as anode in combination with Ti alloy $\left(\mathrm{IrO}_{2} / \mathrm{TiO}_{2}\right)$ as the cathode and found that $\mathrm{Al}$ was more efficient than $\mathrm{Fe}$ as an electrode in both freshwater (Chlorella vulgaris) and marine microalgae (Phaeodactylum tricornutum) dewatering processes [73]. These observations were ascribed to reasons such as conductivity and floc formation from the destabilization of negatively charged microalgae via charge neutralization, that occurs more efficiently for Al than Fe. Since the cathodes are inert, they are the major site for bubble generation via $\mathrm{H}_{2}$ production in electroflotation. However, extensive research that performs bubble size measurements arising from electrolysis using different electrode materials has been undertaken in diverse fields other than in microalgae dewatering and generations [67]. Regardless of this fact, the operating principles are the same and as such key findings in those studies will be drawn on to make a case in this instance. Consequently, Ketkar et al. (1991) generated bubbles of different sizes with platinum $(\mathrm{Pt})$ and stainless-steel plates and found that the latter yielded the finest bubble sizes (diameter: 22-34 $\mu \mathrm{m}$ ) [82]. Moreover, the least measured bubble size generated by electroflotation process is $17 \mu \mathrm{m}$ and was obtained for both $\mathrm{H}_{2}$ (with either platinum ( $\mathrm{Pt}$ ) or Fe electrode) [74] and $\mathrm{O}_{2}$ (with graphite electrode) [83].

Studies have shown a connection between the diameter of the microbubbles and the polished state, either smooth or roughness of the electrode surface; where the current increases led to smaller bubble generation for the rough surface and vice versa for the smooth surface [84]. A similar relationship between the quantity of microbubbles generated and the size of the electrode surface has also been 
reported [85]. For instance, lesser electrolysis time was required to achieve over $90 \%$ microalgae recovery efficiency with No. 30 mesh (diameter $=0.6 \mathrm{~mm}$ ) than with No. 10 mesh (diameter $=2 \mathrm{~mm}$ ) stainless-steel cathode [68]. The authors reasoned that more microbubble generation coupled with faster detachment from the smaller sized electrode surface led to an increase in hydrogen and microalgae cells collisions thus yielding better microalgae removal efficiencies [68].

Though electrode configuration effect on electroflotation has been extensively studied in other fields, it has received less attention in microalgae dewatering applications [86]; although it can alter the distribution of microbubbles. For microalgae dewatering using electroflotation, both batch and continuous laboratory-scale setups have largely been undertaken with vertically placed electrode plate configurations (Table 6) [73,78,79]. A perforated-plate type electrode has been used [17]. A combination of plate- and mesh-type electrodes, placed horizontally at just $20 \mathrm{~mm}$ from the bottom of the electroflotation cell with interelectrode distance of $3 \mathrm{~mm}$ has also been reported [68].

\subsubsection{Electrolyte and/or Microalgal Broth Conditions}

The electrolyte and/or microalgal broth conditions may entail salinity or conductivity, $\mathrm{pH}$, and initial concentration of the microalgae. For a given current density, a more conductive system generally implies shorter electrolysis time, thus lesser energy consumption in order to achieve similar microalgae dewatering performance. These were proven by Vandamme et al. (2011), after conducting laboratory-scale batch experiments with freshwater (Chlorella vulgaris) and marine (Phaeodactylum tricornutum) microalgae. The experimental conditions were the same in both cases (anode $=\mathrm{Al}$; cathode $=\mathrm{IrO}_{2} / \mathrm{TiO}_{2} ;$ inter-electrode distance $=4.4 \mathrm{~cm} ; \mathrm{pH}$ 4) $($ Table 6) [73]. For a shorter electrolysis time of $20 \mathrm{~min}$ with 10 repetitions, the lesser energy consumption was required to reach comparable dewatering efficiency of $85 \%$ using marine macroalgae (conductivity $=43 \mathrm{mS} / \mathrm{cm}$ ); and freshwater system was $30 \mathrm{~min}$ at $88 \%$ dewatering efficiency (conductivity of $0.8 \mathrm{mS} / \mathrm{cm}$ ) [73]. Similarly, by supplementing the growth medium of certain microalgae species like Scenedesmus obliquus with seawater $(10 \%)$, extremely high dewatering performance, greater than $95 \%$, (control sample $<60 \%$ ) was observed. The adscititious sea salts induced self-destabilization of microalgal cells, which caused autoflocculation and led to faster dewatering time [17]. However, at high current densities, the potential problem of hypochlorite formation ( $\mathrm{NaClO}$; bleach) can occur, especially in systems with high $\mathrm{NaCl}$ concentrations as shown by Vandamme et al. (2011) [73] and Gao et al. (2010) [87].

The $\mathrm{pH}$ of the microalgal broth can influence the electroflotation performance via alteration of the sizes of the generated bubbles [67] and/or the quantity of the evolved gases [76]. The $\mathrm{pH}$ is also known to affect the speciation of metal hydroxides, especially of $\mathrm{Al}$, in solution $[72,88]$, which may induce coagulation and result in more efficient dewatering of the microalgal broth. For instance, decrease of initial solution $\mathrm{pH}$ led to enhancement in dewatering efficiency of the electroflotation system [73]. Gao et al. (2010) also reported that at low to neutral initial solution $\mathrm{pH}(4-7)$, cell density of algae was effectively removed [87]. The performance, however, worsened with an initial $\mathrm{pH}$ increase (7-10). A contradictory result was reported by Kim et al. (2012), who by employing a continuous process, rather found that microalgae removal efficiency, increased at a higher $\mathrm{pH}$ of 8 within the first $5 \mathrm{~min}$ of operation [79]. Afterwards, it reverted to the observations as demonstrated by the previous authors. They opined that at lower $\mathrm{pH}$, floc formation intensified, leading to heavier flocs, which may have been too heavy for the microbubbles to float. Thus, instead of floating, more algal flocs rather sank and were recirculated to the cultivation tank reducing cell recovery.

The initial concentrations of the microalgae broth can affect the frequency of inter bubble-microalgae contacts, which is also key to high performance of an electroflotation system. For a transition from batch system to the continuous alternative, Alfafara et al. (2002) identified that the ratio of the current density $\left(\mathrm{A} / \mathrm{dm}^{3}\right)$ and microalgal loading $\left(\mathrm{mg} / \mathrm{m}^{3} \mathrm{~h}\right)$ was a useful operating and scale-up parameter to achieve high microalgae removal efficiency with minimal anode dissolution. This ratio was eventually identified as the charge dose was found to be 250 coulombs, that are required to remove a unit mass of chlorophyll a [78]. Additionally, Kim et al. (2012) successfully designed a continuous system that linked the microalgae 
cultivation and electroflotation harvesting processes in which residual broth, post-microalgal harvesting, was recirculated and reused for microalgae cultivation [80]. This system allowed for a continuous and efficient concentration of microalgae cells as well as drove down costs.

\section{Modified Electroflotation to Improve Biomass Production}

Recently, several modified procedures have been included in the conventional electroflotation or combined with other dewatering approaches to reduce their limitations and improve biomass production. For instance, Zhou et al. (2016) modified an electroflotation process into a two-stage process that inculcated flocculation with chitosan first and a subsequent sequential bubbling flotation via usage of nonsacrificial graphite electrodes. The study showed that the dosage of chitosan, $\mathrm{pH}$, density of microalgal cells, rate of stirring, time of mixing, intensity of current and voltage, and interelectrode distance influenced the efficiency of flocculation. The above-mentioned approach, when employed to harvest biomass of Chlorella species in a $1000 \mathrm{~L}$ pilot electroflotation bench, yielded a concentration rate 50 times that of the input concentration $(0.715 \mathrm{~g} / \mathrm{L})$ and a total recovery efficiency of $90 \%$, with only $23.7 \mathrm{~g}$ of chitosan and $0.43 \mathrm{kWh}$ of electricity needed to harvest $1 \mathrm{~kg}$ of biomass [89]. Similarly, Ryu et al. (2018) evaluated the process of electroflotation, combined with oxidation, for the effective harvesting of bioflocculated algal biomass of green microalgae, Scenedesmus quadricauda, with the simultaneous treatment of the residual pollutant in coke wastewater, after an algal-bacterial process. In this study, a novel boron-doped diamond and $\mathrm{Al}$ electrode was used for the electroflotation process. The authors reported that, for a near complete harvesting of microalgae, a current density of $15 \mathrm{~mA} / \mathrm{cm}^{2}$ or more with electrolysis time of $40 \mathrm{~min}$ with polarity exchange was needed. The study also emphasized that the sequential anodic oxidation via the use of novel electrode possesses the ability to simultaneously mineralize thiocyanate and the residual soluble chemical oxygen demand, which were, otherwise, nondegradable by algal-bacterial mixed culture [90]. Likewise, Ghernaout et al. (2014) investigated the removal of microalgae from Ghrib Dam water in Algeria via electroflotation approach using electrodes from stainless steel. The study revealed that the modification of electroflotation with enhanced electrodes will help in the 100\% removal of microalgal biomass, which is influenced by parameters such as current density, initial solution $\mathrm{pH}$, and the interelectrode distance [91].

Recently, Hung (2017) utilized corrosive rectangle electrodes made up of Fe or Al plates for the electrochemical flotation-mediated dewatering of microalgae (Chlorella species). The study demonstrated that by utilizing a current density of $1.5 \mathrm{~mA} / \mathrm{cm}^{2}$ for $30 \mathrm{~min}$, Al was more beneficial to the electroflotation process than $\mathrm{Fe}$ as $90 \%$ of microalgae was harvested with the former. Additionally, 0.74-1.5 g/L concentration of microalgal biomass was harvested in this study with a power consumption of $1.36 \mathrm{kWh} / \mathrm{kg}$ [92]. Further, Estupinan et al. (2018) designed a unique electroflotation system for the effective harvesting of freshwater microalgae as well as to increase the biomass concentration. In this study, the significance of factors such as voltage, $\mathrm{pH}$, time, and electrode distance as well as types of electrode materials, including $\mathrm{Al}$, steel, $\mathrm{Fe}$, and $\mathrm{Cu}$ were studied for the efficient recovery of biomass (Chlorella vulgaris UTEX 1803 microalgal culture). The results revealed that, $1-2 \mathrm{~cm}$ of electrode distance within 20 min of electroflotation with $15 \mathrm{~V}$ of voltage could yield $40 \%$ and $80 \%$ of biomass via $\mathrm{Cu}$ and $\mathrm{Al}$ electrode, respectively. Moreover, an increment in the voltage to $50 \mathrm{~V}$ and reaction time to $25 \mathrm{~min}$ was proven to increase the biomass recovery efficiency up to $95 \%$, while using Al electrode, as compared to Cu electrode (85\%) [77]. Furthermore, Pandey et al. (2019) also evaluated the electro-coagulation-flocculation approach for the enhanced harvesting of Scenedesmus microalgal species. The authors found that optimized values of $\mathrm{pH}$ 5, electrolysis time of $15 \mathrm{~min}$, interelectrode distance of $2 \mathrm{~cm}$, sedimentation time of $60 \mathrm{~min}$, and current density of $12 \mathrm{~mA} / \mathrm{cm}^{2}$ were required for the enhanced harvesting of microalgal biomass. Besides, this method has been proven to be beneficial in terms of energy utilization, $2.65 \mathrm{kWh} / \mathrm{kg}$, and operational costs, USD 0.29/kg; which yielded $28.6 \pm 1.2 \mathrm{wt}$. $\%$ of microalgal lipids, $8.3 \pm 0.3 \mu \mathrm{g} / \mathrm{mL}$ of chlorophyll a and consequently enhanced the composition of fatty acid methyl ester for the production of biofuels [93]. All these studies have shown that the modification of the conventional electroflotation process for microalgae 
dewatering along with optimized parameters can help to improve the biomass recovery efficiency as summarized in Table 7.

Table 7. Modified electroflotation approach for the efficient recovery of microalgal biomass.

\begin{tabular}{|c|c|c|c|}
\hline Modified Electroflotation & Microalgal Species & Characteristics & References \\
\hline $\begin{array}{l}\text { Graphite electrode, flocculation via chitosan } \\
\text { and sequential bubbling flotation facilitated } \\
\text { electroflotation }\end{array}$ & Chlorella species & $\begin{array}{l}90 \% \text { of total recovery efficiency with } \\
23.7 \mathrm{~g} \text { of chitosan and } 0.43 \mathrm{kWh} \text { of } \\
\text { electricity to harvest } 1 \mathrm{~kg} \text { of biomass }\end{array}$ & [89] \\
\hline $\begin{array}{l}\text { Combination of oxidation, bioflocculation } \\
\text { and electroflotation with boron-doped } \\
\text { diamond and aluminum electrodes }\end{array}$ & $\begin{array}{c}\text { Green Scenedesmus quadricauda } \\
\text { microalgae }\end{array}$ & $\begin{array}{l}\text { Sequential anodic oxidation to } \\
\text { mineralize thiocyanate and residual } \\
\text { soluble chemical oxygen demand, } \\
\text { increased microalgal biomass yield }\end{array}$ & [90] \\
\hline $\begin{array}{l}\text { Stainless steel electrode- mediated } \\
\text { electroflotation }\end{array}$ & Various microalgal species & $\begin{array}{l}100 \% \text { biomass recovery influenced by } \\
\text { current density, initial stage } \mathrm{pH} \text {, and } \\
\text { the electrode distance }\end{array}$ & [91] \\
\hline $\begin{array}{l}\text { Iron or aluminum plate rectangle electrode } \\
\text { facilitated electroflotation }\end{array}$ & Microalgal Chlorella species & $\begin{array}{l}0.74-1.5 \mathrm{~g} / \mathrm{L} \text { of microalgal biomass } \\
\text { concentration harvest with } \\
1.36 \mathrm{kWh} / \mathrm{kg} \text { of power consumption }\end{array}$ & [92] \\
\hline $\begin{array}{l}\text { Aluminum, steel, iron, and copper } \\
\text { electrode mediated electroflotation method }\end{array}$ & Chlorella vulgaris UTEX 1803 & $\begin{array}{c}\text { Aluminum electrode mediated } \\
\text { electroflotation leads to } 95 \% \text { of } \\
\text { biomass recovery efficiency with } 50 \mathrm{~V} \\
\text { of voltage and reaction time to } 25 \mathrm{~min}\end{array}$ & [77] \\
\hline Electro-coagulation-flocculation approach & Scenedesmus microalgal species & $\begin{array}{l}\text { Microalgal lipid yield }(28.6 \pm 1.2 \\
\text { wt. } \%) \text {, chlorophyll a }(8.3 \pm 0.3 \mu \mathrm{g} / \mathrm{mL}) \text {, } \\
\text { and enhanced fatty acid methyl ester } \\
\text { composition with } 2.65 \mathrm{kWh} / \mathrm{kg} \text { of } \\
\text { energy utilization and USD } 0.29 / \mathrm{kg} \text { of } \\
\text { operation cost. }\end{array}$ & [93] \\
\hline
\end{tabular}

\section{Cost Analysis of Dewatering Approaches for Microalgal Biomass Production}

Generally, high energy consumption with low operational costs are the qualitative terms that are used to express the performance of harvesting and dewatering processes of microalgal biomass production. Table 8 provides a summary of various approaches of algal biomass production and their economic performance. Fasaei et al. (2018) recently evaluated the technoeconomic status with a special focus on consumption of energy, processing costs, and resource recovery of each harvesting and dewatering approach, that are used for large-scale microalgal biomass production. The study showed that the operating cost of open cultivation system for dilute solutions is in the range of $€ 0.5-2 / \mathrm{kg}$ of algae, whereas their energy consumption is in the range of $0.2-5 \mathrm{kWh} / \mathrm{kg}$ of algae. Note that the requirement of energy can be reduced via flocculation approach in the dewatering and harvesting of dilute systems. However, the operating cost of these systems is similar to mechanical methods, due to the loss of flocculants and requirement of chemicals during the process. Likewise, there is a decrement in the operational cost and energy requirement of the closed cultivation system to $€$ $0.1-0.6 / \mathrm{kg}$ of algae and $0.1-0.7 \mathrm{kWh} / \mathrm{kg}$ of algae, respectively. Further, the study revealed that the cost of labor would be a major factor that increases the total cost, which can be reduced via automation, which may, however, increase the initial investment cost. Furthermore, the study recommended that the single-step operation is highly beneficial only to provide a high concentration of biomass, while two-step operations, namely pressure filtration with centrifugation or spiral plate technology are considered as beneficial from the economic point of view [94]. Besides, it is worth noting that the centrifugation, spiral plate technology, and membrane filtration, that are highly recommended as conventional dewatering strategies, require high capital cost—which is the major limitation in terms of the prospects for large-scale commercial microalgal biomass production $[95,96]$.

The cost analysis can be calculated by setting a reference condition with parameters, such as concentration and stream of feed, concentration of the product into the dryer, the content of water in product after drying, concentration of product between harvesting and dewatering, and operational hours, for system evaluation. The cost analysis of harvesting and dewatering step in a microalgal 
biomass production system will be evaluated by the respective currency (USD or $€$ ) per year using the initial mass balance Equation of algal biomass in each step as mentioned in Equation (3).

$$
F_{\text {in }} C_{\text {in }}=F_{\text {out }} C_{\text {out }}+F_{\text {co, out }} C_{\text {co, out }}
$$

where, $F$ represents the in or out volumetric flow rates for algal biomass streams $\left(\mathrm{m}^{3} / \mathrm{h}\right)$, co is the costream with water and a small lost algal biomass fraction and $C$ is the algal biomass concentration $\left(\mathrm{kg} / \mathrm{m}^{3}\right)$ in each stream.

Table 8. Economic performances of various algal biomass production systems.

\begin{tabular}{ccc}
\hline Type of Algal Biomass Production & Economic Performance & References \\
\hline Open cultivation system for dilute solutions & $€ 0.5-2 / \mathrm{kg}$ of algae & {$[94]$} \\
\hline Closed cultivation system & $€ 0.1-0.6 / \mathrm{kg}$ of algae & {$[94]$} \\
\hline Single-step harvesting and dewatering using centrifugation process & AUD 12.10 & {$[15]$} \\
\hline Single-step harvesting and dewatering using sedimentation process & AUD 3.7-4.1 & {$[15]$} \\
\hline Single-step harvesting and dewatering using primary flotation USD 0.833 & AUD 1.86-2.08 & {$[15]$} \\
\hline Single-step harvesting and dewatering using secondary flotation & AUD 0.833 & {$[15]$} \\
\hline Secondary harvesting and dewatering using filtration & AUD 0.22-0.66 & {$[15]$} \\
\hline Secondary harvesting and dewatering using centrifugation & AUD 1.21 & {$[15]$} \\
\hline Dewatering in settling ponds & USD 5.8 & {$[97]$} \\
\hline Dewatering in membrane & USD 178 & {$[97]$} \\
\hline Dewatering in centrifuge & USD 478 & {$[97]$} \\
\hline Dewatering in dissolved air flotation & USD 29 & {$[97]$} \\
\hline Dewatering in filter press & USD 70 & {$[97]$} \\
\hline Dewatering in electrocoagulation & USD 157 & {$[97]$} \\
\hline
\end{tabular}

Later, the yearly costs of harvesting and dewatering can be calculated by the formula given by Lee et al. (2010) as mentioned in Equation (4) [98].

$$
P \mathrm{c}=(0.5 I+M) \times C_{\mathrm{I}}+C_{\mathrm{I}} / A+C_{\mathrm{e}}+C_{\mathrm{c}}+C_{1}+C_{\text {loss }}
$$

where, the production costs per kilogram of algal biomass produced are represented by:

$$
P_{\mathrm{c}, \text { algae }}=P_{\mathrm{e}} / Y_{\text {total }}
$$

In this Equation, $C_{I}$ is the total investment cost in the, respective country's currency, $I$ is the rate of interest in $\%, M$ is the $\%$ of maintenance cost, $C_{\mathrm{I}} / A$ is the yearly depreciation in currency per year over $A$ as the depreciation time (year), $C_{\mathrm{e}}$ is the energy cost, $C_{\mathrm{c}}$ is the consumable costs, $C_{1}$ is the labor cost, mentioned in currency per year, and $Y_{\text {total }}$ is the total kilogram of biomass produced in a year. Further, an optional term, $C_{\text {loss }}$, can also be included in the Equation to represent the loss of algae in terms of cost per year. In general, the investment cost will be calculated for each scenario from the total costs of equipment purchased, that are multiplied with Lang factor, which is a purchase cost multiplier to cover the costs for electrical facilities, piping, instrumentation, construction, buildings, electrical facilities, engineering, and contractors fee [99]. In addition, the scaling factor rule can be used for extrapolation of purchase costs to other capacities as mentioned in Equation (6).

$$
\text { Cost } \mathrm{B} / \operatorname{cost} \mathrm{A}=(\text { size } \mathrm{B} / \text { size } \mathrm{A})
$$

where, cost $A$ and $B$ represent the unit operation purchase cost with capacity size $A$ and $B$, and $n$ is the corresponding equipment scaling factor in the range $10-100 \%$ of maximal capacity [100]. 
In another study by Garg (2013), the cost of harvesting Chlorella species in a 10,000 L capacity, using distinct harvesting and dewatering methods were evaluated. It was estimated that $55 \mathrm{kWh} / 10 \mathrm{~m}^{3}$ of total energy was consumed with Australian dollar (AUD 12.10) energy cost in single-step harvesting and dewatering centrifugation process. Whilst, the estimated total cost of primary harvesting and dewatering methods, such as sedimentation is $\$ 3.7-4.1$, primary flotation is $\$ 1.86-2.08$, and secondary flotation is $\$ 0.833$. Moreover, the estimated total cost of secondary harvesting and dewatering approaches, such as filtration and centrifugation are $\$ 0.22-0.66$ and $\$ 1.21$, respectively [15]. It can be noted from the study that the flotation method of microalgal harvesting and dewatering to produce biomass leads to a reduction in total cost, compared to other dewatering approaches. Further, Davis et al. (2016) recently evaluated the economics and process design for the algal biomass production in open pond systems via dewatering approaches, such as hollow fiber membrane, gravity settling and centrifugation, for downstream conversion to increase the solid biomass concentration up to $20 \mathrm{wt} . \%$. In this study, the installation capital costs of the dewatering technology in the case of settling ponds, membrane, and centrifuges were $\$ 5.8, \$ 178$, and $\$ 478$, respectively, per volume feed rate, $\$ /\left(\mathrm{m}^{3} /\right.$ day $)$. Likewise, the installation capital cost of alternative dewatering approaches, such as DAF has been estimated as $\$ 29$, whereas electrocoagulation and filter press were $\$ 157$ and $\$ 70$, respectively, per volume feed rate to $\$ /\left(\mathrm{m}^{3} /\right.$ day). Even though DAF method can lead to lower installation cost compared to other dewatering approaches, the high power demand and operational cost for flocculants such as chitosan, may eventually increase the total cost of the process. Thus, it has been identified that DAF and electrocoagulation can reduce the total cost of final algal biomass concentration to $20 \%$, compared to other approaches and also eliminates the centrifugation process [97]. It is evident from these studies that flotation dewatering approach can be useful in reducing the total cost of the microalgal biomass production. Even though electrical costs for electroflotation may increase the cost in every cycle (depending on the electric cost per unit in each country), it can be compensated for by the overall total cost during the large-scale production of microalgal biomass, as compared to other approaches.

\section{Future Perspective}

It is evident from the previous sections that the electroflotation harbors great potential as an effective dewatering method for the large-scale production of microalgal biomass. The main advantage of utilizing the electroflotation approach for microalgal dewatering is the capability for microbubble generation, which allows for merits such as large surface area-to-volume ratio to remove tiny particles, elevated efficiency of flotation, operational ease, and compactness to promote large-scale microalgae production [101]. Despite the aforementioned merits, the dependency of the process on current flow can, thus, be limited by a low conductivity of the medium, which will inadvertently lead to the application of high current densities. To avoid this and make the process useful economically, a certain conductivity is required to maintain excellent current flow in freshwater systems especially [71]. Further, it can be noted that Ti is widely used as the cathode material, during the electroflotation process in corrosive water, due to its high stability. The Ti cathodes are, however, costly and may increase the total cost for large-scale microalgal production. Consequently, nickel (Ni) has been used as the cathode material in recent times, since it possesses a low overpotential for hydrogen evolution, which lessens energy consumption [102]. Furthermore, reactor design of a single-stage system with a vertical flow has been revealed to be highly beneficial in elevated separation efficiency, due to their uniform flow distribution. However, certain fragments may drop from the scum skimmer and separation chamber, which may not lead to floating again [101]. Moreover, it is possible to regulate bubble size via applied current in electroflotation with minimum turbulence and this approach has been identified to be highly safe, when the system runs at a low voltage of 5-20 V [76]. In addition, this approach can be used as an alternative to DAF, when the dissolution of air is challenging. Electroflotation will increase the density of sludge and lower the water losses [103]. Besides, it is problematic using common metals and alloys as anode since they may lead to severe electrochemical corrosion, thereby limiting the 
usage of electroflotation processes in large-scale applications and industries [104]. The phenomenon of oxide layer formation on the electrode surface is called electrode passivation, which may further reduce the efficiency of microalgal dewatering process via electroflotation [105]. Even though the addition of chloride ions, regular electrode cleaning, turbulence increment, and polarity inversion are available as alternatives to avoid electrode passivation in electroflotation [106], the costs involved in these processes are high [103]. Thus, there is a need for an alternative and nonconventional approach in electroflotation approach to overcome these challenges and increase its efficiency in large-scale dewatering for microalgal biomass production.

The efficiency of electrodes in electroflotation methods can be improved by coating them with catalytic nanoparticles. For instance, Talaiekhozani et al. (2020) recently immobilized $\mathrm{TiO}_{2}$ nanoparticles in the electrodes to improve electroflotation efficiency along with microreactor [107]. Further, it can be noted that all other limitations of the electroflotation method are related to the conductivity and voltage. Thus, alterations in the surface charge of microalgae via catalytic nanoparticles or ions, that are released by nanomaterials can increase the electric charge potential and can help in elevating the electroflotation ability. Recently, Ge et al. (2015) utilized magnetic iron oxide nanoparticles for rapid algal separation, and examined the influence of surface coating, ultraviolet irradiation and magnetic field on the efficiency of the process [108]. Moreover, the modification of surface charge and eventual alteration of the electric potential will facilitate thickening of microalgal biomass via electroflotation and therefore lead to efficient dewatering of microalgal biomass. The addition of chemically synthesized nanoparticles, however, may lead to potential toxicity towards microalgae, and correspondingly affect its usage in the production of value-added products. Thus, biosynthesized nanoparticles are proposed to be beneficial in improving the surface charge of microalgae to critically increase their dewatering efficiency. Furthermore, the cost of electricity in electroflotation is a major factor, which increases the total cost, during large-scale harvesting and dewatering of microalgal biomass. Alternative renewable energy resources, such as solar or wind energy-mediated power supply will reduce the cost involved in the electroflotation process in the future, provided their installation and maintenance costs are less.

\section{Conclusions}

Electroflotation has been revealed to be an excellent cost-effective dewatering approach for the large-scale production of microalgal biomass, when compared to other conventional dewatering methods. Several advancements in electroflotation by way of modifications have also been introduced to increase the efficiency of electroflotation in the dewatering process, such as utilizing unique composite materials as electrodes and combining electroflotation with other conventional dewatering methods. The overall cost of microalgal production, while using electroflotation as the dewatering approach, is much lesser compared to other dewatering methods. However, there are certain limitations, such as lack of efficient anode material, issues related to conductivity and electrode passivation in electroflotation, which affects the large-scale production of microalgal biomass and the potential application in industries. Thus, implications of futuristic technologies, such as nanotechnology and renewable energy in electroflotation will help to overcome the challenges and render this approach as a better dewatering method to produce a higher concentration of microalgal biomass in the future.

Author Contributions: Conceptualization, M.K.D. and J.J.; writing-original draft preparation, J.J., M.R.H., S.Y.L., D.D.S. and M.K.D.; writing-review and editing, J.J., D.D.S. and M.K.D.; supervision, M.K.D. All authors have read and agreed to the published version of the manuscript.

Funding: This research received no external funding.

Acknowledgments: The author (Jaison Jeevanandam) acknowledges the support of FCT-Fundação para a Ciência e a Tecnologia (Base Fund UIDB/00674/2020 and Programmatic Fund UIDP/00674/2020, Portuguese Government Funds), ARDITI-Agência Regional para o Desenvolvimento da Investigação Tecnologia e Inovação through the project M1420-01-0145-FEDER-000005-CQM ${ }^{+}$(Madeira 14-20 Program). All the other authors would like to thank their respective department and university for the support during the preparation of this manuscript.

Conflicts of Interest: The authors declare no conflict of interest. 


\section{References}

1. Satyanarayana, K.G.; Mariano, A.B.; Vargas, J.V.C. A review on microalgae, a versatile source for sustainable energy and materials. Int. J. Energy Res. 2011, 35, 291-311. [CrossRef]

2. Milledge, J.J.; Heaven, S. A review of the harvesting of micro-algae for biofuel production. Rev. Environ. Sci. Bio/Technol. 2013, 12, 165-178. [CrossRef]

3. Manirafasha, E.; Ndikubwimana, T.; Zeng, X.; Lu, Y.; Jing, K. Phycobiliprotein: Potential microalgae derived pharmaceutical and biological reagent. Biochem. Eng. J. 2016, 109, 282-296. [CrossRef]

4. Vigani, M.; Parisi, C.; Rodríguez-Cerezo, E.; Barbosa, M.J.; Sijtsma, L.; Ploeg, M.; Enzing, C. Food and feed products from micro-algae: Market opportunities and challenges for the EU. Trends Food Sci. Technol. 2015, 42, 81-92. [CrossRef]

5. Mourelle, M.L.; Gómez, C.P.; Legido, J.L. The potential use of marine microalgae and cyanobacteria in cosmetics and thalassotherapy. Cosmetics 2017, 4, 46. [CrossRef]

6. Renuka, N.; Guldhe, A.; Prasanna, R.; Singh, P.; Bux, F. Microalgae as multi-functional options in modern agriculture: Current trends, prospects and challenges. Biotechnol. Adv. 2018, 36, 1255-1273. [CrossRef]

7. Xu, X.; Gu, X.; Wang, Z.; Shatner, W.; Wang, Z. Progress, challenges and solutions of research on photosynthetic carbon sequestration efficiency of microalgae. Renew. Sustain. Energy Rev. 2019, 110, 65-82. [CrossRef]

8. Yusoff, F.M.; Banerjee, S.; Nagao, N.; Imaizumi, Y.; Shariff, M.; Toda, T. Use of microalgae pigments in aquaculture. In Pigments from Microalgae Handbook; Springer: Cham, Switzerland, 2020; pp. 471-513.

9. Spier, M.R.; Peron-Schlosser, B.; Paludo, L.C.; Gallo-García, L.A.; Zanette, C.M. Microalgae as enzymes biofactories. In Handbook of Microalgae-Based Processes and Products; Elsevier: Amsterdam, The Netherlands, 2020; pp. 687-706.

10. Rumin, J.; Nicolau, E.; Junior, R.G.d.O.; Fuentes-Grünewald, C.; Picot, L. Analysis of scientific research driving microalgae market opportunities in Europe. Mar. Drugs 2020, 18, 264. [CrossRef]

11. Novoveská, L.; Ross, M.E.; Stanley, M.S.; Pradelles, R.; Wasiolek, V.; Sassi, J.-F. Microalgal carotenoids: A review of production, current markets, regulations, and future direction. Mar. Drugs 2019, 17, 640. [CrossRef]

12. Kirnev, P.C.S.; Carvalho, J.C.; Vandenberghe, L.P.S.; Karp, S.G.; Soccol, C.R. Technological mapping and trends in photobioreactors for the production of microalgae. World J. Microbiol. Biotechnol. 2020, 36, 1-9. [CrossRef]

13. Jeevanandam, J.; Choudhary, V.; Selvam, J.D.; Danquah, M.K. The Bioeconomy of production of microalgal pigments. In Pigments from Microalgae Handbook; Springer: Cham, Switzerland, 2020; pp. 325-362.

14. Sing, S.F.; Isdepsky, A.; Borowitzka, M.A.; Lewis, D.M. Pilot-scale continuous recycling of growth medium for the mass culture of a halotolerant Tetraselmis sp. in raceway ponds under increasing salinity: A novel protocol for commercial microalgal biomass production. Bioresour. Technol. 2014, 161, 47-54. [CrossRef] [PubMed]

15. Sharma, K.K.; Garg, S.; Li, Y.; Malekizadeh, A.; Schenk, P.M. Critical analysis of current microalgae dewatering techniques. Biofuels 2013, 4, 397-407. [CrossRef]

16. Musa, M.; Doshi, A.; Brown, R.; Rainey, T.J. Microalgae dewatering for biofuels: A comparative techno-economic assessment using single and two-stage technologies. J. Clean. Prod. 2019, 229, 325-336. [CrossRef]

17. Shin, H.; Kim, K.; Jung, J.-Y.; Bai, S.C.; Chang, Y.K.; Han, J.-I. Harvesting of Scenedesmus obliquus cultivated in seawater using electro-flotation. Korean J. Chem. Eng. 2017, 34, 62-65. [CrossRef]

18. Kadir, W.N.A.; Lam, M.K.; Uemura, Y.; Lim, J.W.; Lee, K.T. Harvesting and pre-treatment of microalgae cultivated in wastewater for biodiesel production: A review. Energy Convers. Manag. 2018, 171, 1416-1429. [CrossRef]

19. Chen, C.-Y.; Yeh, K.-L.; Aisyah, R.; Lee, D.-J.; Chang, J.-S. Cultivation, photobioreactor design and harvesting of microalgae for biodiesel production: A critical review. Bioresour. Technol. 2011, 102, 71-81. [CrossRef]

20. Piasecka, A.; Nawrocka, A.; Wiącek, D.; Krzemińska, I. Agro-industrial by-product in photoheterotrophic and mixotrophic culture of Tetradesmus obliquus: Production of $\omega 3$ and $\omega 6$ essential fatty acids with biotechnological importance. Sci. Rep. 2020, 10, 6411. [CrossRef]

21. Park, S.; Kim, J.; Park, Y.; Kim, S.; Cho, S.; Yu, J.; Kang, C.; Lee, T. Comparison of trophic modes to maximize biomass and lipid productivity of micractinium inermum NLP-F014. Biotechnol. Bioprocess. Eng. 2018, 23, $238-245$. [CrossRef]

22. Jin, H.; Zhang, H.; Zhou, Z.; Li, K.; Hou, G.; Xu, Q.; Chuai, W.; Zhang, C.; Han, D.; Hu, Q. Ultrahigh-cell-density heterotrophic cultivation of the unicellular green microalga Scenedesmus acuminatus and application of the cells to photoautotrophic culture enhance biomass and lipid production. Biotechnol. Bioeng. 2020, 117, 96-108. [CrossRef] 
23. Pleissner, D.; Smetana, S. Estimation of the economy of heterotrophic microalgae-and insect-based food waste utilization processes. Waste Manag. 2020, 102, 198-203. [CrossRef]

24. Leong, W.-H.; Lim, J.-W.; Lam, M.-K.; Uemura, Y.; Ho, Y.-C. Third generation biofuels: A nutritional perspective in enhancing microbial lipid production. Renew. Sustain. Energy Rev. 2018, 91, 950-961. [CrossRef]

25. Khan, M.I.; Shin, J.H.; Kim, J.D. The promising future of microalgae: Current status, challenges, and optimization of a sustainable and renewable industry for biofuels, feed, and other products. Microb Cell Fact. 2018, 17, 36. [CrossRef]

26. Salama, E.-S.; Kurade, M.B.; Abou-Shanab, R.A.; El-Dalatony, M.M.; Yang, I.-S.; Min, B.; Jeon, B.-H. Recent progress in microalgal biomass production coupled with wastewater treatment for biofuel generation. Renew. Sustain. Energy Rev. 2017, 79, 1189-1211. [CrossRef]

27. Chew, K.W.; Chia, S.R.; Show, P.L.; Yap, Y.J.; Ling, T.C.; Chang, J.-S. Effects of water culture medium, cultivation systems and growth modes for microalgae cultivation: A review. J. Taiwan Inst. Chem. Eng. 2018, 91, 332-344. [CrossRef]

28. Suparmaniam, U.; Lam, M.K.; Uemura, Y.; Lim, J.W.; Lee, K.T.; Shuit, S.H. Insights into the microalgae cultivation technology and harvesting process for biofuel production: A review. Renew. Sustain. Energy Rev. 2019, 115, 109361. [CrossRef]

29. Narala, R.R.; Garg, S.; Sharma, K.K.; Thomas-Hall, S.R.; Deme, M.; Li, Y.; Schenk, P.M. Comparison of microalgae cultivation in photobioreactor, open raceway pond, and a two-stage hybrid system. Front. Energy Res. 2016, 4, 29. [CrossRef]

30. Cruz, Y.R.; Aranda, D.A.G.; Seidl, P.R.; Diaz, G.C.; Carliz, R.G.; Fortes, M.M.; da Ponte, D.A.M.P.; de Paula, R.C.V. Cultivation systems of microalgae for the production of biofuels, biofuels-State of development. Krzysztof Biernatintechopen 2018, 199-219. [CrossRef]

31. Harun, R.; Singh, M.; Forde, G.M.; Danquah, M.K. Bioprocess engineering of microalgae to produce a variety of consumer products. Renew. Sustain. Energy Rev. 2010, 14, 1037-1047. [CrossRef]

32. Grobbelaar, J.U. Photosynthetic characteristics of Spirulina platensis grown in commercial-scale open outdoor raceway ponds: What do the organisms tell us? J. Appl. Phycol. 2007, 19, 591-598. [CrossRef]

33. Ramos de Ortega, A.; Roux, J.C. Production of Chlorella biomass in different types of flat bioreactors in temperate zones. Biomass 1986, 10, 141-156. [CrossRef]

34. Cuaresma, M.; Janssen, M.; Vílchez, C.; Wijffels, R.H. Horizontal or vertical photobioreactors? How to improve microalgae photosynthetic efficiency. Bioresour. Technol. 2011, 102, 5129-5137. [CrossRef]

35. Hosseini, A.; Shariati, M. Pilot culture of three strains of Dunaliella salina for $\beta$-carotene production in open ponds in the center region of Iran. World J. Microbiol. Biotechnol. 2006, 22, 1003-1006. [CrossRef]

36. Qiang, H.; Richmond, A. Optimizing the population density inIsochrysis galbana grown outdoors in a glass column photobioreactor. J. Appl. Phycol. 1994, 6, 391-396. [CrossRef]

37. Muller-Feuga, A.; Pruvost, J.; Le Guédes, R.; Le Déan, L.; Legentilhomme, P.; Legrand, J. Swirling flow implementation in a photobioreactor for batch and continuous cultures of Porphyridium cruentum. Biotechnol. Bioeng. 2003, 84, 544-551. [CrossRef]

38. Tan, X.; Lam, M.K.; Uemura, Y.; Lim, J.W.; Wong, C.Y.; Lee, K.T. Cultivation of microalgae for biodiesel production: A review on upstream and downstream processing. Chin. J. Chem. Eng. 2018, 26, 17-30. [CrossRef]

39. Pulz, O. Photobioreactors: Production systems for phototrophic microorganisms. Appl. Microbiol. Biotechnol. 2001, 57, 287-293. [PubMed]

40. Jorquera, O.; Kiperstok, A.; Sales, E.A.; Embirucu, M.; Ghirardi, M.L. Comparative energy life-cycle analyses of microalgal biomass production in open ponds and photobioreactors. Bioresour. Technol. 2010, 101, 1406-1413. [CrossRef]

41. Moazami, N.; Ashori, A.; Ranjbar, R.; Tangestani, M.; Eghtesadi, R.; Nejad, A.S. Large-scale biodiesel production using microalgae biomass of Nannochloropsis. Biomass Bioenergy 2012, 39, 449-453. [CrossRef]

42. Rogers, J.N.; Rosenberg, J.N.; Guzman, B.J.; Oh, V.H.; Mimbela, L.E.; Ghassemi, A.; Betenbaugh, M.J.; Oyler, G.A.; Donohue, M.D. A critical analysis of paddlewheel-driven raceway ponds for algal biofuel production at commercial scales. Algal Res. 2014, 4, 76-88. [CrossRef]

43. Li, Y.; Zhang, Q.; Wang, Z.; Wu, X.; Cong, W. Evaluation of power consumption of paddle wheel in an open raceway pond. Bioprocess. Biosyst. Eng. 2014, 37, 1325-1336. [CrossRef]

44. Duan, Y.; Shi, F. Bioreactor design for algal growth as a sustainable energy source. In Reactor and Process Design in Sustainable Energy Technology; Elsevier: Cham, Switzerland, 2014; pp. 27-60. 
45. Pugliese, A.; Biondi, L.; Bartocci, P.; Fantozzi, F. Selenastrum capricornutum a new strain of algae for biodiesel production. Fermentation 2020, 6, 46. [CrossRef]

46. Koru, E.; Delice, G.G. Microalgae And Their Cultivation System To Produce Biodiesel. IBU J. Sci. Technol. 2014, 2, 73-84.

47. Gupta, P.L.; Lee, S.-M.; Choi, H.-J. A mini review: Photobioreactors for large scale algal cultivation. World J. Microbiol. Biotechnol. 2015, 31, 1409-1417. [CrossRef] [PubMed]

48. Zakariah, N.A.; Rahman, N.A.; Hamzah, F.; Jahi, T.M. Cultivation of system of green microalgae Botryococcus braunii: A review. J. Technol 2015, 76, 1-5. [CrossRef]

49. Brennan, L.; Owende, P. Biofuels from microalgae-A review of technologies for production, processing, and extractions of biofuels and co-products. Renew. Sustain. Energy Rev. 2010, 14, 557-577. [CrossRef]

50. Huntley, M.E.; Redalje, D.G. $\mathrm{CO}_{2}$ mitigation and renewable oil from photosynthetic microbes: A new appraisal. Mitig. Adapt. Strateg. Glob. Chang. 2007, 12, 573-608. [CrossRef]

51. Rodolfi, L.; Chini Zittelli, G.; Bassi, N.; Padovani, G.; Biondi, N.; Bonini, G.; Tredici, M.R. Microalgae for oil: Strain selection, induction of lipid synthesis and outdoor mass cultivation in a low-cost photobioreactor. Biotechnol. Bioeng. 2009, 102, 100-112. [CrossRef]

52. Barros, A.I.; Gonçalves, A.L.; Simões, M.; Pires, J.C.M. Harvesting techniques applied to microalgae: A review. Renew. Sustain. Energy Rev. 2015, 41, 1489-1500. [CrossRef]

53. Liu, J.; Song, Y.; Qiu, W. Oleaginous microalgae Nannochloropsis as a new model for biofuel production: Review and analysis. Renew. Sustain. Energy Rev. 2017, 72, 154-162. [CrossRef]

54. Vandamme, D.; Foubert, I.; Muylaert, K. Flocculation as a low-cost method for harvesting microalgae for bulk biomass production. Trends Biotechnol. 2013, 31, 233-239. [CrossRef]

55. Uduman, N.; Qi, Y.; Danquah, M.K.; Forde, G.M.; Hoadley, A. Dewatering of microalgal cultures: A major bottleneck to algae-based fuels. J. Renew. Sustain. Energy 2010, 2, 012701. [CrossRef]

56. Cui, Y.; Yuan, W.; Cheng, J. Understanding $\mathrm{pH}$ and ionic strength effects on aluminum sulfate-induced microalgae flocculation. Appl. Biochem. Biotechnol. 2014, 173, 1692-1702. [CrossRef]

57. Roselet, F.; Vandamme, D.; Roselet, M.; Muylaert, K.; Abreu, P.C. Effects of pH, salinity, biomass concentration, and algal organic matter on flocculant efficiency of synthetic versus natural polymers for harvesting microalgae biomass. Bioenergy Res. 2017, 10, 427-437. [CrossRef]

58. Gerardo, M.L.; Van Den Hende, S.; Vervaeren, H.; Coward, T.; Skill, S.C. Harvesting of microalgae within a biorefinery approach: A review of the developments and case studies from pilot-plants. Algal Res. 2015, 11, 248-262. [CrossRef]

59. Pragya, N.; Pandey, K.K.; Sahoo, P.K. A review on harvesting, oil extraction and biofuels production technologies from microalgae. Renew. Sustain. Energy Rev. 2013, 24, 159-171. [CrossRef]

60. Rashid, N.; Rehman, S.U.; Han, J.-I. Rapid harvesting of freshwater microalgae using chitosan. Process. Biochem. 2013, 48, 1107-1110. [CrossRef]

61. Rashid, N.; Rehman, M.S.U.; Han, J.-I. Use of chitosan acid solutions to improve separation efficiency for harvesting of the microalga Chlorella vulgaris. Chem. Eng. J. 2013, 226, 238-242. [CrossRef]

62. Teixeira, C.M.L.L.; Teixeira, P.C.N. Evaluation of the flocculation efficiency of chlorella vulgaris mediated by moringa oleifera seed under different forms: Flour, seed cake and extracts of flour and cake. Braz. J. Chem. Eng. 2017, 34, 65-74. [CrossRef]

63. Kandasamy, G.; Shaleh, S.R.M. Harvesting of the Microalga Nannochloropsis sp. by bioflocculation with mung bean protein extract. Appl. Biochem. Biotechnol. 2017, 182, 586-597. [CrossRef]

64. Al-Hattab, M.; Ghaly, A.; Hammouda, A. Microalgae harvesting methods for industrial production of biodiesel: Critical review and comparative analysis. J. Fundam. Renew. Energy Appl. 2015, 5, 5.

65. Show, K.-Y.; Lee, D.-J.; Chang, J.-S. Algal biomass dehydration. Bioresour. Technol. 2013, 135, 720-729. [CrossRef] [PubMed]

66. Danquah, M.K.; Ang, L.; Uduman, N.; Moheimani, N.; Forde, G.M. Dewatering of microalgal culture for biodiesel production: Exploring polymer flocculation and tangential flow filtration. J. Chem. Technol. Biotechnol. 2009, 84, 1078-1083. [CrossRef]

67. Chen, X.; Chen, G. Electroflotation. In Electrochemistry for the Environment; Springer: Cham, Switzerland, 2010; pp. 263-277. 
68. Luo, S.; Griffith, R.; Li, W.; Peng, P.; Cheng, Y.; Chen, P.; Addy, M.M.; Liu, Y.; Ruan, R. A continuous flocculants-free electrolytic flotation system for microalgae harvesting. Bioresour. Technol. 2017, 238, 439-449. [CrossRef] [PubMed]

69. Marrone, B.L.; Lacey, R.E.; Anderson, D.B.; Bonner, J.; Coons, J.; Dale, T.; Downes, C.M.; Fernando, S.; Fuller, C.; Goodall, B. Review of the harvesting and extraction program within the National Alliance for Advanced Biofuels and Bioproducts. Algal Res. 2018, 33, 470-485. [CrossRef]

70. Richardson, J.W.; Johnson, M.D.; Lacey, R.; Oyler, J.; Capareda, S. Harvesting and extraction technology contributions to algae biofuels economic viability. Algal Res. 2014, 5, 70-78. [CrossRef]

71. Mickova, I.L. Advanced electrochemical technologies in wastewater treatment. Part II: Electro-flocculation and electro-flotation. Am. Sci. Res. J. Eng. Technol. Sci. 2015, 14, 273-294.

72. Mollah, M.Y.; Morkovsky, P.; Gomes, J.A.; Kesmez, M.; Parga, J.; Cocke, D.L. Fundamentals, present and future perspectives of electrocoagulation. J. Hazard. Mater. 2004, 114, 199-210. [CrossRef]

73. Vandamme, D.; Pontes, S.C.V.; Goiris, K.; Foubert, I.; Pinoy, L.J.J.; Muylaert, K. Evaluation of electro-coagulation-flocculation for harvesting marine and freshwater microalgae. Biotechnol. Bioeng. 2011, 108, 2320-2329. [CrossRef]

74. Glembotskii, V.; Mamakov, A.; Ramanov, A.; Nenno, V. 11th International Mineral Processing Congress, Cagliari, Italy, 20-26 April 1975; Università di Cagliari: Cagliari, Italy, 1975; pp. 562-581.

75. Ndikubwimana, T.; Chang, J.; Xiao, Z.; Shao, W.; Zeng, X.; Ng, I.S.; Lu, Y. Flotation: A promising microalgae harvesting and dewatering technology for biofuels production. Biotechnol. J. 2016, 11, 315-326. [CrossRef]

76. Kyzas, G.Z.; Matis, K.A. Electroflotation process: A review. J. Mol. Liq. 2016, 220, 657-664. [CrossRef]

77. Castellaños-Estupiñana, M.A.; Sánchez-Galvisa, E.M.; García-Martínezb, J.B.; Barajas-Ferreirab, C.; Zuorroc, A.; Barajas-Solano, A.F. Design of an electroflotation system for the concentration and harvesting of freshwater microalgae. Chem. Eng. Trans. 2018, 64,1-6.

78. Alfafara, C.G.; Nakano, K.; Nomura, N.; Igarashi, T.; Matsumura, M. Operating and scale-up factors for the electrolytic removal of algae from eutrophied lakewater. J. Chem. Technol. Biotechnol. Int. Res. Process. Clean Technol. 2002, 77, 871-876. [CrossRef]

79. Kim, J.; Ryu, B.-G.; Kim, B.-K.; Han, J.-I.; Yang, J.-W. Continuous microalgae recovery using electrolysis with polarity exchange. Bioresour. Technol. 2012, 111, 268-275. [CrossRef] [PubMed]

80. Sanchez-Galvis, E.M.; Cardenas-Gutierrez, I.Y.; Contreras-Ropero, J.E.; García-Martínez, J.B.; Barajas-Solano, A.F.; Zuorro, A. An innovative low-cost equipment for electro-concentration of microalgal biomass. Appl. Sci. 2020, 10, 4841. [CrossRef]

81. Rahmani, A.; Zerrouki, D.; Djafer, L.; Ayral, A. Hydrogen recovery from the photovoltaic electroflocculation-flotation process for harvesting Chlorella pyrenoidosa microalgae. Int. J. Hydrogen Energy 2017, 42, 19591-19596. [CrossRef]

82. Ketkar, D.R.; Mallikarjunan, R.; Venkatachalam, S. Electroflotation of quartz fines. Int. J. Miner. Process. 1991, 31, 127-138. [CrossRef]

83. Burns, S.; Yiacoumi, S.; Tsouris, C. Microbubble generation for environmental and industrial separations. Sep. Purif. Technol. 1997, 11, 221-232. [CrossRef]

84. Lumanauw, D. Hydrogen Bubble Characterization in Alkaline Water Electrolysis. Master Thesis, University of Toronto, Toronto, ON, Canada, 2000.

85. Sarkar, M.S.K.A.; Evans, G.; Donne, S. Bubble size measurement in electroflotation. Miner. Eng. 2010, 23, 1058-1065. [CrossRef]

86. Pishgar, Z.; Samimi, A.; Mohebbi-Kalhori, D.; Shokrollahzadeh, S. Comparative study on the harvesting of marine chlorella vulgaris microalgae from a dilute slurry using autoflocculation-sedimentation and electrocoagulation-flotation methods. Int. J. Environ. Res. 2020, 14, 615-628. [CrossRef]

87. Gao, S.; Du, M.; Tian, J.; Yang, J.; Yang, J.; Ma, F.; Nan, J. Effects of chloride ions on electro-coagulation-flotation process with aluminum electrodes for algae removal. J. Hazard. Mater. 2010, 182, 827-834. [CrossRef]

88. Duan, J.; Gregory, J. Coagulation by hydrolysing metal salts. Adv. Coll. Interface Sci. 2003, 100, 475-502. [CrossRef]

89. Adesanya, V.O.; Cadena, E.; Scott, S.A.; Smith, A.G. Life cycle assessment on microalgal biodiesel production using a hybrid cultivation system. Bioresour. Technol. 2014, 163, 343-355. [CrossRef] [PubMed]

90. Ryu, B.-G.; Kim, J.; Han, J.-I.; Kim, K.; Kim, D.; Seo, B.-K.; Kang, C.-M.; Yang, J.-W. Evaluation of an electro-flotation-oxidation process for harvesting bio-flocculated algal biomass and simultaneous treatment of residual pollutants in coke wastewater following an algal-bacterial process. Algal Res. 2018, 31, 497-505. [CrossRef] 
91. Ghernaout, D.; Benblidia, C.; Khemici, F. Microalgae removal from Ghrib Dam (Ain Defla, Algeria) water by electroflotation using stainless steel electrodes. Desalin. Water Treat. 2015, 54, 3328-3337. [CrossRef]

92. Hung, H.V. Research on harvesting of microalgae Chlorella Sp. by electrochemical flotation method using corrosive electrodes. Vietnam J. Sci. Technol. 2017, 55, 14. [CrossRef]

93. Pandey, A.; Shah, R.; Yadav, P.; Verma, R.; Srivastava, S. Harvesting of freshwater microalgae Scenedesmus sp. by electro-coagulation-flocculation for biofuel production: Effects on spent medium recycling and lipid extraction. Environ. Sci. Pollut. Res. 2020, 27, 3497-3507. [CrossRef]

94. Fasaei, F.; Bitter, J.H.; Slegers, P.M.; van Boxtel, A.J.B. Techno-economic evaluation of microalgae harvesting and dewatering systems. Algal Res. 2018, 31, 347-362. [CrossRef]

95. Pahl, S.L.; Lee, A.K.; Kalaitzidis, T.; Ashman, P.J.; Sathe, S.; Lewis, D.M. Harvesting, thickening and dewatering microalgae biomass. In Algae for Biofuels and Energy; Springer: Cham, Switzerland, 2013; pp. 165-185.

96. Gerardo, M.L.; Zanain, M.A.; Lovitt, R.W. Pilot-scale cross-flow microfiltration of Chlorella minutissima: A theoretical assessment of the operational parameters on energy consumption. Chem. Eng. J. 2015, 280, 505-513. [CrossRef]

97. Lee, A.K.; Lewis, D.M.; Ashman, P.J. Energy requirements and economic analysis of a full-scale microbial flocculation system for microalgal harvesting. Chem. Eng. Res. Des. 2010, 88, 988-996. [CrossRef]

98. Lang, H.J. Simplified approach to preliminary cost estimates. Chem. Eng. 1948, 55, 112-113.

99. Ruiz, J.; Olivieri, G.; de Vree, J.; Bosma, R.; Willems, P.; Reith, J.H.; Eppink, M.H.M.; Kleinegris, D.M.M.; Wijffels, R.H.; Barbosa, M.J. Towards industrial products from microalgae. Energy Environ. Sci. 2016, 9, 3036-3043. [CrossRef]

100. Davis, R.; Markham, J.; Kinchin, C.; Grundl, N.; Tan, E.C.D.; Humbird, D. Process Design and Economics for the Production of Algal Biomass: Algal Biomass Production in Open Pond Systems and Processing through Dewatering for Downstream Conversion; Technical report; National Renewable Energy Lab.(NREL): Golden, CO, USA, 2016.

101. Comninellis, C.; Chen, G. Electrochemistry for the Environment; Springer: Cham, Switzerland, 2010; Volume 2015.

102. Palani, V. Evaluation of Cyanobacteria Removal in an Integrated Process of Electroflotation and Rapid Filtration Using Plastic Filter Media. Master's Thesis, Norges teknisk-naturvitenskaplige universitet (NTNU, Norwegian University of Science and Technology), Trondheim, Norway, 2019.

103. Sillanpää, M.; Shestakova, M. Electrochemical Water Treatment Methods: Fundamentals, Methods and Full Scale Applications; Butterworth-Heinemann: Oxford, UK, 2017.

104. Martínez-Huitle, C.A.; Rodrigo, M.A.; Scialdone, O. Electrochemical Water and Wastewater Treatment; Butterworth-Heinemann: Oxford, UK, 2018.

105. Martelli, G.N.; Ornelas, R.; Faita, G. Deactivation mechanisms of oxygen evolving anodes at high current densities. Electrochim. Acta 1994, 39, 1551-1558. [CrossRef]

106. Daneshvar, N.; Sorkhabi, H.A.; Kasiri, M.B. Decolorization of dye solution containing Acid Red 14 by electrocoagulation with a comparative investigation of different electrode connections. J. Hazard. Mater. 2004, 112, 55-62. [CrossRef] [PubMed]

107. Talaiekhozani, A.; Mosayebi, M.R.; Fulazzaky, M.A.; Eskandari, Z.; Sanayee, R. Combination of $\mathrm{TiO}_{2}$ microreactor and electroflotation for organic pollutant removal from textile dyeing industry wastewater. Alex. Eng. J. 2020, 59, 549-563. [CrossRef]

108. Ge, S.; Agbakpe, M.; Wu, Z.; Kuang, L.; Zhang, W.; Wang, X. Influences of surface coating, UV irradiation and magnetic field on the algae removal using magnetite nanoparticles. Environ. Sci. Technol. 2015, 49, 1190-1196. [CrossRef]

Publisher's Note: MDPI stays neutral with regard to jurisdictional claims in published maps and institutional affiliations.

(C) 2020 by the authors. Licensee MDPI, Basel, Switzerland. This article is an open access article distributed under the terms and conditions of the Creative Commons Attribution (CC BY) license (http://creativecommons.org/licenses/by/4.0/). 